\title{
DE MATROZEN EN SOLDATEN OP DE SCHEPEN DER OOST-INDISCHE COMPAGNIE.
}

\author{
noor Dr. J. DE HULLU.
}

Den 18 September (1669) is alhier volgens de gewoonte in alle straten en stegen met trommels en pijpen, schalmeien en trompetten openlijk uitgeroepen dat elk, die lust en genegenheid had om naar Indië te gaan, zich bij de heeren Bewindhebbers der Edele Compagnie kon aanmelden, waarop ik mij terstond aan het Oost-Indische Huis vervoegde. Doch aangezien reeds alle officiersplaatsen waren vergeven heb ik geen hoogeren post kunnen bekomen dan dien van adelborst. Nadat de heeren mijn naam hadden opgeteekend en de plaats en het land, waar ik van daan kwam, gaf men mij dadelijk het handgeld benevens een van een slot voorziene kist om mijn goed in te bergen, terwijl zij mij verder geluk en voorspoed toewenschten en dat $\mathrm{ik}$ gezond en wel uit Indië mocht terugkeeren.» ${ }^{1}$ Met die woorden ongeveer beschrijft een Duitsch handwerksman, dien de reislust van uit zijn werkwinkel de wijde wereld in dreef, de wijze waarop hij in den nazomer van 1669 te Amsterdam in dienst trad bij de Oost-Indische Compagnie. Biijkbaar heeft hij het geluk gehad niet in de handen te moeten vallen van de zielverkoopers, de welbekende ronselaars, die tegen den tijd dat de Oost-Indische schepen het zeegat stonden uit te gaan ijverig in de weer waren om de Compagnie aan matrozen en soldaten te helpen en dezen, zoolang tot dat zij aan boord gingen, kost en inwoning plachten te verschaffen. ${ }^{2}$

Wanneer de dag, dat de Bewindhebbers tot het aannemen van volk zitting hielden, daar was, trokken de zielverkoopers of volkhouders, gelijk zij met een anderen naam genoemd werden,

1 Jörg Franz Müller's Reisindrukken (ed. Heeres in De Navorscher 1902), blz. 11 .

2 Zie mijn opstel: "Zieken en dokters op de schepen der Oost-Indische Compagnie" in deze Bijdragen, deel 67, blz. 248 vlg. 
met hun gasten naar het Oost-Indische Huis om ze in den dienst van de Compagnie te laten opnemen. Was de toeloop van gegadigden groot, dan kostte het somwijlen de grootste moeite om al de aangebrachte manschappen aan emplooi te helpen en vielen er tooneelen voor zooals die, welke door den auteur van een Duitsche reisbeschrijving in 1694 te Amsterdam werden aanschouwd. Ik heb met verbazing gezien, verhaalt hij, hoe die arme menschen aandringen met een geweld als wilden zij het Huis bestormen, waarbij soms veel slagen vallen ja zelfs wel bebloede koppen worden opgeloopen. De zielverkoopers staan achter hen en sporen hun volkje dapper aan om toch naar voren te dringen, zoodat de eene den ander zoekt vóór te geraken en zij tot tegen de vensters opklauteren om toch maar dicht bij de deur te wezen, wanneer deze opengaat. Soms halen de zielverkoopers kleine. fleschjes brandewijn en geven die aan hun luidjes om ze daarmede op te monteren. Zoodra de deur opengaat neemt het uitdeelen van slagen en klappen eerst goed zijn begin, want ieder wil de voorste zijn, alsof er iets heerlijks te verkrijgen ware, terwijl het toch met alle recht den naam mag dragen van zich voor slaaf te verkoopen. '

Nadat de Bewindhebbers met het aannemen hadden gedaan, schoten nu en dan nog een vrij groote menigte liefhebbers over. Dan zag men de volkhouders verlegen heen en weer loopen en aan dezen of genen goeden vriend een paar maanden gage presenteeren zoo hij hun gasten nog aan een plaats kon helpen, want daar werden er ook na dien altoos nog eenige aangenomen. Wanneer dit mislukte voerden zij hen naar het Prinsenhof, waar de Admiraliteit zetelde, om indien het mogelijk was plaatsing voor hen te bekomen bij 's lands marine. Slaagden zij ook hier niet, dan liepen zij gevaar hun gasten te moeten laten gaan met verlies van alles, wat zij aan hun onderhoud en logies ten koste hadden gelegd. Er bleef nu geen andere uitweg open dan dat men ze als soldaten bij het landleger plaatste en daartoe de hulp inriep van een soort van individuen, "kat en hond» geheeten, die onder de hand en in het geheim hen nog wel wisten over te leveren aan de nooit ontbrekende wervers. Deze "kat en hond», het uitvaagsel van de heele ronselaarsbende, waren onder anderen ook de gewone

1 Christoph Langhansz, Neue Ost-Indianisehe Reise, Leipzig 1705, S. 16, 17. 
toevlucht van koopvaardijkapiteins, die gebrek hadden aan bootsgezellen. $\mathrm{Zij}$ liepen dan de kroegen af om geschikte sujetten op te sporen en ontvingen tot belooning voor elken persoon, dien zij aanbrachten, een dukaton of drie gulden. ${ }^{1}$

Welke laaghartige praktijken de zielverkoopers en hun aanhang te baat namen blijkt uit een memorie, in 1776 aan de Kamer Amsterdam aangeboden, waar onder meer het volgende te lezen staat: «het is onmogelijk voor $U$ EdelAchtbaarhedens te weten hoe de naam van ceeleverkoopers in geheel Duitschland een schrik voor $U$ EdelAchtbaarhedens dienst inboezemt niet alleen om den kost, om het opsluiten, om de behandeling ${ }^{2}$, dat al harde artikels zijn, maar ook omdat alom bekend is dat zij, die absoluut naar de Oost willen, tegen hun zin naar de West, ten oorlog, ja zelfs naar Engelsche koloniën te varen gedwongen worden, nimmer weten zij waar heen. En gebruikten zij niet alle soorten van bedriegerijen, beloften, vreemde adressen etc., de aanbreng der volkhouders zoude zeer gering zijn». ${ }^{3}$ Ongelukkigerwijs moesten de Bewindhebbers destijds zulke misbruiken wel door de vingers zien, want daar de Compagnie gedurig al meer en meer zwarigheden had ondervonden om het benoodigde getal matrozen en soldaten te verkrijgen, was zij van de zielverkoopers allengs zoozeer afhankelijk geworden dat zonder hun medewerking aan het bemannen van haar schepen niet te denken viel. ${ }^{4}$ Een ander gevolg van dezen toestand was de enorme toeneming van de zielverkoopers. Op plaatsen, daar zij voorheen onbekend waren, telde men er in 1778 tot twintig, dertig en meer, terwijl er alleen binnen Amsterdam op dat tijdstip naar schatting meer werden aangetroffen dan er hoofden waren op een Compagniesbodem. ${ }^{5}$

Zoodra iemand voor den dienst was geëngageerd, ging hij op het soldijcomptoir der Compagnie een transport- of schuldbrief passeeren. ${ }^{6}$ In den regel een waarde vertegenwoordigend

1 Langhansz. a. w. S. 18, 19.

2 Zie mijn opstel: „Zieken en dokters op de schepen der O.-I. Compagnie."

3 Reflectiën van Hendrik Meijers aan de Kamer Amsterdam 22 Januari 1776.

4 J. Harger, Verhandeling over den scheepsbouw, Middelburg 1784, blz. 355.

s. Veirac, Verhandeling over de besmettelijke rotkoorts op de uitgaande O.-I. Schepen, Middelburg 1778, blz. 23.

6 Langhansz, a. w. S. 20. 
van 150 gulden ', waren deze transportbrīeven zoo ingericht dat degene, tot wiens last zij liepen, daarbij aan de Bewindhebbers verzocht om die som "aan toonder dezes uit te betalen uit zijn eerste te verdienen gage, te weten zoo wanneer de scheepsboeken, zijn rekeningen ${ }^{2}$ of andere genoegzame bescheiden overgekomen zullen zijn en daarbij blijke, dat hij op zijn verdiende gage zooveel te goed heeft ${ }^{3}{ }^{3}$ Met den transportbrief en de twee maanden soldij, welke hij op de hand ontving, betaalde nu de geëngageerde hetgeen hij aan den zielverkooper was verschuldigd zoowel voor de genoten kost en inwoning als voor de uitrusting van plunje enz., waarmede deze hem voor de reis had voorzien. ${ }^{4}$ Alles te zamen genomen, berekende een oudgast in het allerlaatst van de $17^{\mathrm{e}}$ eeuw, moesten de arme kerels, welke de zielverkoopers hadden aangebracht, maanden en maanden, ja jaren in dienst zijn geweest vooraleer zij zeggen konden: "nu eerst win ik geld voor mijzelf, wat al mijn vorige loon heeft de zielverkooper reeds weg ". ${ }^{5}$ Niet anders oordeelt een tweede oudgast, die een vijftig jaar later dit punt aanroerde. Men "knevelt, schat en scheert deze arme menschen dermate (spreekt hij) dat bij een nauwkeurige examinatie metterdaad op een doorslaande wijze zal worden ondervonden, dat de meeste derzelve niet kunnen worden geconsidereerd te varen voor hun zelve maar voor deze en gene, - en wie weet al voor wie? - en ten behoeve van deze of gene zoogenaamde zielverkoopers moeten maken transport, uit hetwelke onmiddellijk komt te proflueeren dat deze meerendeels zeer behoeftige menschen gedurende alzulke zware heen- en wederreizen zelden kunnen rekenen effen op te wezen. Men diende ten minste aan den gemeenen man [te laten] een volkomen faculteit om hunzelven te engageeren zonder onder die zoogenaamde Moedertjesvleugelen te moeten schuilen. ${ }^{6}$

1 Christophorus Frikius, Elias Hesse en Christophorus Schweitzer, Drie seer aenmercklycke Reijsen, Utrecht 1694, blz. 332, 333; Johann Wilhelm Vogel, Ost-Indianische Reisebeschreibung, Altenburg 1716, Vorbericht; Langhansz, a. w. S. 20; Reflectiën van Hendrik Meijers; Veirac, a. w. blz. 21.

2 Dat is: geauthentiseerde extracten uit de boeken, waaruit bleek hoeveel zij te vorderen hadden of verschuldigd waren.

s Blijkens de formulieren gelijk die in verschillende scheepsboeken zijn bewaard gebleven.

4 Langhansz, a. w. S. 21; Frikius, Hesse en Schweitzer, a. w. blz. 332, 333.

s Langhansz, a. w. S. 22.

6 "Aanmerkingen over den jegenwoordigen toestand der zaken van de generale Nederlandsche geoctrooijeerde Oost-Indische Compagnie in Indiën", van omstreeks 1750 door een ongenoemde (Papieren Radermacher, Rijksarchief). 
Oppervlakkig beschouwd heeft het dus den schijn alsof het zielverkoopersbedrijf een ware geldwinning was. Eenige weken onderhoud te verschaffen met het allerslechtste en allergoedkoopste voedsel ${ }^{1}$ - omstreeks 1678 kon het geschieden voor vier à vijf gulden ter week ${ }^{2}$, - een uitrusting te leveren welke, met inbegrip van een rijksdaalder drinkgeld dien zij aan hun gasten gaven, hun ten hoogste op een dertig gulden kwam te staan ${ }^{3}$, en voor dat alles betaald te worden met twee maanden gage, die achttien tot dertig gulden uitmaakten, het lijkt uit een finantieel oogpunt bezien geen onvoordeelig zaakje. In de werkelijkheid echter was het anders. Wie waarborgde dat de in dienst getredene in staat zou zijn om het transport of zelfs maar de twee maanden gage op de hand te verdienen, dat hij in leven blijven zou tot hij zooveel op zijn rekening te goed had, of dat de bodem, daar hij op voer, niet op de reis zou vergaan, in welk geval de gage van de bemanning volgens den artikelbrief ophield van den dag af, dat de ramp plaats had? Daar kwam bij dat de volkhouders veelal te slecht bij kas waren om op betaling te kunnen wachten tot de boeken en rekeningen overkwamen en, zooals wij zagen, konden zij vóór dien tijd ten soldijcomptoire geen penning hoegenaamd los krijgen. Wilden zij dus geld hebben om bij hun leveranciers, die hun niet zelden alles op den borg hadden geleverd, hun schuld te kunnen voldoen, dan bleef er geen ander middel over dan dat zij de transportceelen tegen contante betaling zochten over te doen aan de zoogenaamde ceelkoopers ${ }^{4}$, een klasse van personen die van zulke financiëele operatiën hun beroep maakten. Doch het spreekt van zelf dat de ceelkoopers bij de overneming dier transportbrieven tegelijk met den loopenden intrest ook de risico verdisconteerden, waar de houder aan bloot stond, zoodat zij er slechts de helft van het nominale bedrag soms zelfs niet meer dan zestig, vijftig of veertig gulden voor besteedden. 5 "Het pary der transportkoopers, zoo men gewoon is te zeggen

1 Zie mijn opstel: "Zieken en dokters op de schepen der O.-I. Compagnie”, in deze Bijdragen deel $67 \mathrm{blz} .250$.

? Vogel, a. w. Vorbericht.

3 Langhansz, a. w. S. 22.

4 Dit verkoopen van de transportceelen door de volkhouders was zóó algemeen dat zij er hun naam van ceelverkoopers, bij verbastering zielverkoopers, aan ontleenden.

5 Vogel, a. w. Vorbericht; Langhansz, a. w. S. 22. 
(aldus de reeds aangehaalde memorie van 1776), regelt zich naar de tusschenruimte des gelds gemis en de hoeveelheid der sterfgevallen, waarom dan ook de transporten rijzen en dalen, gelijk het voorbeeld geleerd heeft dat men voor veertig gulden bijna geen verkoopen kon, toen men vier man op één het pary noemde, de intrest van geld daarbij gerekend.» ${ }^{1}$ Het gevolg hiervan was dat de ceelkoopers met het meeste van de profijten doorgingen, immers door het groote getal transporten, dat zij plachten te koopen, leden zij gewoonlijk weinig of geen schade, want mocht er al eens een van degenen, tot wier last zij liepen, komen te sterven, zij stierven toch niet allen, daargelaten nog dat de risico over verschillende schepen was verdeeld. Zoodoende werden de ceelkoopers rijk, terwijl de zielverkoopers meerendeels zoo arm waren dat zij ten slotte zelf voor matroos of soldaat naar Indië moesten gaan. ${ }^{2}$

Als de geëngageerden eenige dagen na hun aanneming op het Oost-Indische Huis den eed van trouw afgelegd en den artikelbrief besworen hadden, werd enkele dagen later alweder bij trommelslag uitgeroepen dat een ieder zijn bagage op de gereed liggende lichters zou laten brengen en aanstonds op het Oost-Indische Huis verschijnen moest. Hier werden zij opnieuw gemonsterd, men las hun nog eens den artikelbrief voor, reikte de wapens uit en voerde hen vervolgens onder den toelonp van de samengestroomde menigte, die when beweende en beklaagde als of zij reeds allen ten doode waren opgeschreven ", en met het geklank van trommels en trompetten naar de lichters, door welke zij naar de op de reede zeilree liggende schepen zouden worden overgebracht. Nadat zij bij hun aankomst aldaar door den schipper met een toespraak waren verwelkomd begon het inladen van de bagage, een drukte van geweld waarmede wegens het groote getal opvarenden een heele tijd was gemoeid ${ }^{3}$ en die, eer alles op zijn bestemde plaats was geschikt, van het scheepsdek een doolhof maakte, waar kisten, kassen en los goed in de grootst mogelijke wanorde als een berg zoo hoog op en door elkander lagen. Enkele dagen na dien kwamen een paar Bewindhebbers met het Compagniesjacht ter reede om de manschappen van schip tot schip voor de

1 Reflectiën van Hendrik Meijers aan de Kamer Amsterdam 1776.

2 Langhansz, a. w. S. 22.

${ }^{3}$ Von Wurmb en Von Wolzogen, Briefe, Gotha 1794, S. 31, 32. 
laatste maal te monsteren en nog eens den artikelbrief voor te lezen. Wanneer daarop de wind in den gunstigen hoek schoot verscheen de loods aan boord, de ziekentrooster las een predikatie voor en liet een psalm zingen, de schipper voegde daar een ernstig woord aan toe en straks daarop zette de vloot met volle zeilen koers naar de Landen van Overzee, onder het donderend gebulder van haar kanonnen, en van alle vaartuigen, die op de reede voor anker lagen, met eereschoten begroet. ${ }^{1}$

Met uitzondering van den koopman, den onderkoopman, den assistent, den boekhouder, den ziekentrooster, den opper- en den onderchirurgijn, den kommandeur van de soldaten, den konstapel, den bottelier, den kok, den verschen balie, ${ }^{2}$ den oppertimmerman, de jongens en die "voor jongens medekwamen ${ }^{3}$ werden, zoodra men in het ruime sop kwam, ${ }^{4}$ alle opvarenden naar het voorschrift van den đrtikelbrief ${ }^{5}$ in twee soms ook wel drie ${ }^{6}$ groepen gerangschikt, ieder met een van de hoofd- en eenige mindere officieren alsmede een aparten kwartiermeester aan het hoofd ${ }^{7}$ en onderscheidenlijk de namen dragende van het Prinsen-, het Graaf Maurits- en het Graaf Ernst-kwartier. ${ }^{8}$ Tot welke van de drie de verschillende manschappen behoorden stond aangewezen op twee of dirie staten

1 Müller, a. w. blz. 13-17.

2 De versche balie was een matroos, die het vleesch te weeken zette en voor het beuken van de stokvisch zorgen moest.

3 Nicolaas de Graaff, Oost-Indische Spiegel, blz. 37. - Echter waren de jongens blijkens de roergangerslijsten van sommige schepen toch ook tot het waarnemen van den roergang verplicht, zij schijnen dus ook soms bij de kwartieren te zijn ingedeeld. De kok en de bottelier met hun bijbehoorend volk maakten het zoogenaamd "ketelskwartier" uit, zie mijn opstel „De voeding op de schepen der Oost-Indische Compagnie" in deze Bijdragen deel 67, blz. 547 en De Graaff a. w. blz. 37; David Tappen, Funffzehnjährige Ost. Indianische Reisebeschreibung, Hannover en Wolffenbuttel 1704, d. 264.

1 Johann von der Behr, Ost-Indianische Reisebeschreibung, Jena 1668, S. 10; Johann Schreyer, Neue Ost-Indianische Reiszbeschreibung, Leipzig 1681, S. 4; Vogel; a. w. Vorbericht; Harger, a. w. blz. 486.

5 Artikelbrieven van 1634, 1658, 1672, 1742 resp. art. 128, 107, 107, 113.

6 Von der Behr, t.a.p.; Johann Jacob Saar, Ost-Indianische funfzehnjährige Kriegsdienste, Nürnberg 1662, S. 4, spreken van drie, de meeste andere reisbeschrijvingen van twee. Volgens De Graaff t.a.p. waren er drie op de uit- en twee op de retourreis.

7 De Graaff, t. a.p.

$s$ Von der Behr, Saar, Schreyer, Vogel, Harger op de aangehaalde plaatsen; Frikius, Hesse en Schweitzer, a. w. blz. 341. 
of rollen, die op het schip waren opgehangen. ${ }^{1}$ Wanneer er veel zieken aan boord waren werd het gezondste kwartier weder gesplitst. ${ }^{2}$ Elk kwartier had zijn eigen zieken te verplegen ${ }^{3}$ en moest op zijn beurt voor de dagelijksche reiniging van het schip zorgen $^{4}$ alsmede den waak- en roergang waarnemen. ${ }^{5}$ Alle avonden, te ongeveer acht uren, ${ }^{6}$ kwam de provoost boven, liet de scheepsklok luiden ${ }^{7}$ en riep, na met een dik stuk hout driemaal tegen den grooten mast te hebben geslagen tot teeken dat de »eerste» wacht inging, met luider stem: "Hoort mannen hoort, van de wacht en van de straat, of de provoost zal geld of pand rapen, Niemand drinke hem dronken in bier of wijn, 't $\mathrm{Zal}$ van avond Prinsekwartier ${ }^{8}$ zijn, Prinsekwartier houdt goede wacht, God die verleen ons een goede nacht, Een goede nacht en goede vree, Geluk en behouden reis daarmee. Boven die zijn wacht is, Naar kooi die zijn beurt is, Luidt de klok, Verlost den man van het roer en den uitkijk.» ${ }^{9} \mathrm{Na}$ deze taptoe, als men het zou kunnen noemen, mocht aan boord door niemand meer licht gebrand worden ${ }^{10}$ en begaven diegenen, welke bij het afgeroepen kwartier waren geplaatst, zich aan dek, waar de kwartiermeester aan een ieder zijn bijzondere taak aanwees. ${ }^{11}$

Terwijl de meesten te waak gingen om, als de wind draaide, onmiddellijk bij de hand te zijn voor het veranderen van de zeilen en het aanhalen van de touwen, ${ }^{12}$ zat een ander, telkens voor een uur, in den mast of op de raas op den uitkijk of zich ook vreemde schepen of land vertoonden. ${ }^{13}$ Weer een ander

1 Saar, t.a.p.

2 Saar, a. w. S. 5.

3 Artikelbrieven van de vloot in 1601 uitgevaren onder Jacob van Heemskerk, $1634,1658,1672,1742$ resp. art. $21,85,67,67$ en 75 .

4 Als voren resp. art. 32, 86, 67, 67 en 76 .

${ }^{5}$ Als voren van $1634,1658,1672$ en 1742 resp. art. 128, 107, 107, 113.

${ }^{6}$ Harger, a. w. blz. 486.

7 Von der Behr, a. w. S. 10; Saar, a. w. S. 4; Peter Kolbe, Beschrijving van de Kaap de Goede Hoop, Amst. 1727, I blz. 24; De Graaff, a. w. blz. 29.

$s$ Of, al naar gelang het zoo uitkwam: Graaf Maurits - dan wel Graaf Ernstkwartier.

9 David Tappen, Funffzehnzährige Ost-Indianische Reisebeschreibung,

Hannover en Wolffenbuttel 1704, S. 222 ; Kolbe, a. w. I. blz. 24.

10 Vogel, a. w. Vorbericht.

11 De Graaff, a. w. blz. 37.

13 Von der Behr, a. w. S. 10.

13 Kolbe, a. w. I, blz. 24. 
stond aan het roer om de roerpen te bestieren zooals het hem gekommandeerd werd door den stuurman, die van het halfdek gestadig de oogen gevestigd hield op het kompas en het windvaantje van den grooten mast. ${ }^{1}$ Tot dienst van den "roerganger « bevonden zich in een huisje vóór of bij de roerpen, dat des nachts door een lamp werd verlicht, het "nachthuis» gelijk het heette, een paar kompassen. ${ }^{2}$ Bij stormweer of onstuimige zee, als één man het roer niet regeeren kon, werd hij in zijn werk door drie, vier of meer anderen geholpen. ${ }^{3}$ Wie van het te roer gaan vrij begeerden te zijn, konden tegen een belooning van omtrent 40 gulden ${ }^{*}$ voor den duur van de geheele reis hun taak overdragen, »besteden" als het heette, aan anderen, meestal gewone matrozen, de zoogenaamde "waarnemers", onder wie naderhand het gezamenlijk bedrag van wat de besteders waren verschuldigd gelijkelijk werd verdeeld. ${ }^{5}$ Op dezelfde wijze werd somwijlen ook de verplichting tot het doen van den uitkijk afgekocht. ${ }^{6}$ Bovendien moesten de opperofficieren orde stellen dat "alle nachten drie- of viermaal in alle kwartieren de ronde werd gedaan bij degenen, die zijluiden daartoe bij beurten zouden committeeren, om alle onraad, desordre en inzonderheid alle samenrottingen en conspiratiën onder het volk te voorkomen.» ${ }^{7}$ Eindelijk werd het dienstdoende kwartier een half uur voordat zijn wacht uit was door den kwartiermeester aan de pompen gezet opdat het zijn opvolger een droog schip zou kunnen overgeven. $^{8}$

1 Tappen, a. w. S. 270.

2 Tappen, a. w. S. 259.

3 Tappen, t. a.p.; Nicolaas Witsen, Scheepsbouw en bestier, Amsterdam 1671, blz. 406.

4 Deze som wordt genoemd door Langhansz (a. w. S. 609), wiens reizen plaats hadden gedurende het tijdvak 1694-1701. Op het schip Velsen, dat in 1757 uitging, werd blijkens het scheepsboek door de besteders hetzelfde bedrag betaald roor de gansche reis, terwijl een paar, die eerst van de Kaap af waren medegevaren, elk 24 gulden betaalden. Op den in 1762 uitgezeilden bodem Het Huis te Bijweg werd blijkens het scheepsboek 34 à 36 gulden betaald.

${ }^{5}$ Blijkens het hiervóór aangehaalde scheepsboek van het schip Velsen en tal van andere scheepsboeken.

6 Saar, a. w. S. 4.

7 Artikelbrief voor de schepen, die dit tegenwoordige jaar 1622 mitsgaders ook anno 1623 naar Oost-Indië staan te varen, art. 13, en die van 1634, 1658, 1672 art. 13. Vgl. ook Kolbe, a. w. I, blz. 24.

s Tappen, a. w. S. 269; De Graaff, a. w. blz. 29. 
Wanneer de zandlooper voor de achtste maal was omgekeerd en de klok, die telken reize als dit gebeurde zooveel slagen sloeg als er glazen of halve uren waren verstreken, ${ }^{1}$ het uur van twaalven afkondigde, was de eerste wacht afgeloopen en begon de "hondewacht." Onderwijl de manschappen van het afgaande kwartier zich gereed maakten om ter ruste te gaan, werd het kwartier gewekt, dat thans aan de beurt was. Dit geschiedde niet meer met het slaan tegen den mast gelijk op het aangaan van de "eerste» wacht plaats had, maar op den volgenden trant. Een kwartiermeester, matroos of ook wel een tweetal matrozen ${ }^{2}$ begaf zich onder in het schip en hief daar de woorden aan van den roerzang: "Hier zeilen wij met God verheven, God wil ons onze zonden vergeven, $\mathrm{Al}$ onze zonden en misdaad, God is ons troost en toeverlaat. Kwaart, Kwaart, Graaf Maurits kwartier te roer en te waak zal gaan, God die verleen ons Zijnen vree, Geluk en behouden reis daarmee. Graaf Maurits kwartier wilt komen boven, Voor een goede reis willen wij God loven, God loven en danken zijnen Naam, Komt heruit kwartier in Godes naam. God die wil ons goede schip bewaren Met al de maats die daarop varen, Mast, roer, kiel, staaf, steng en want En al wat daar om- en anehangt Staat altemaal in Godes hand, God die bewaar ons goede schip Voor eenig kwaad en ongeluk, Voor zee, voor zand, voor vuur en brand, Voor de helsche booze vijand, Voor al het kwaad Ons God bewaart. Kwaart, kwaart, 't is lang genoeg gekwaart, Komt laat ons naar de wakers gaan En zien wat gasten daarvoor staan Met een pijpje toebak in de hand En rooken eens voor 't Vaderland. Versche balie, malle gek, Rijs uit je kooi, verversch je spek ${ }^{3}$, En laat je glazen niet stille staan, Wij willen zoo gaarn naar kooi toe gaan. Heruit kwartier met alle man, Roept God den Heer van harten an, Van harten en een blijde zin, Zoo verleent Hij ons mooi weer en voor de wind ${ }^{4}$. Volgens Witsen, die in zijn bekende werk over den scheepsbouw een vrij wat afwijkenden text mededeelt, voegden $z$ ij «dikmaals

1 Saar, a. w. S. 4.

2 Müller, a. w. blz. 16; Tappen, a. w. S. 267; Frikius, Hesse en Schweitzer, a. w. blz. 341. - Volgens Witsen, a. w. blz. 416, werd de roerzang gezongen door twee matrozen, die de een voor den ander achter onder het verdek stonden, en dat wel vers om vers op het bevel van den kwartiermeester.

3 Zie mijn opstel „De voeding op de schepen der O.-I. Compagnie".

4 Tappen, a. w. S. 267. 
hier nog deze en andere regels achter:» "Niemand zal daar in de helle Als de kok met zijn gezelle En de bottelier met zijn maat En het mannetje dat met het stokje slaat ${ }^{1}$. Versche balie, goede heer, Stijg uit uw kooi en doe je geen zeer, Verversch uw visch». "Doch deze (laat hij er deftiglijk op volgen) deze, als niet betamende vermengd te zijn met een stichtig lied, ga voorbij» ${ }^{2}$. Daarop sprongen die van het tweede kwartier uit de kooi om het eerste af te lossen en insgelijks acht glazen of vier uur lang te waken. Te vier uur 's ochtends begon de dagwacht, welke weder door het Prinsekwartier werd waargenomen en insgelijks vier uur duurde, daarna waakte het Graaf Mauritskwartier in de "voormiddagwacht" tot twaalf uur en vervolgens weer het Prinsekwartier in de "namiddagwacht" ${ }^{3}$. Tusschen de "namiddagwacht» en het opzetten van de "eerste» wacht viel de zoogenaamde "platvoet» ${ }^{4}$. Zoo er echter boos weer opkwam werd de onderlinge afwisseling van de kwartieren niet langer in acht genomen maar onder het geroep van "Overal Overal» alle man zonder onderscheid door den provoost uit de kooi gejaagd om boven te komen en daar handen aan het werk te slaan ${ }^{5}$. Iets dergelijks geschiedde wanneer het "Ree Ree» weerklonk tot teeken dat het schip moest worden gewend om te laveeren ${ }^{6}$.

Uit den aard der zaak verkeerde het scheepsvolk op die reizen, waar het in drie kwartieren was verdeeld, in veel gustiger omstandigheden dan wanneer er slechts twee waren. Immers het maakte een groot verschil uit of men maar tenauwernood vier dan wel acht uren achtereen kon slapen. In het eerste geval sprong het van de wacht komende volk om maar tijd te winnen vaak in de kooi met zijn natte plunje aan het lijf, in het tweede gunde het zich ten minste den tijd om de kleeren uit te trekken. $\mathrm{Zij}$ gingen dan zoo goed als naakt te bed, want van een genoegzamen voorraad om zich bij mistig en regen-

1 Dat is de provoost met zijn gerechtsstok.

2 Witsen, a. w. blz. 416.

3 Vogel, a. w. Vorbericht; Frikius, Hesse en Schweitzer a. w. blz. 341: Harger, a. w. blz. 486. Instuctie voor de scheepsleggers.

- Volgens De Graaff, a. w. blz. 37, gaf men den naam van de platvoet aan de drie glazen, welke aan de „eerste" wacht voorafgingen.

${ }^{5}$ Witsen, a. w. blz. 436; De Graaff, a. w. blz. 29; Tappen, a. w. S. 27; Harger, a. w. blz. 486 vlg.

6 Saar, a. w. S. 1,4 ; Tappen, a. w. S. 27. 
achtig weder gestadig te kunnen verschoonen en verkleeden was bij de matrozen en soldaten natuurlijk geen sprake ${ }^{1}$ : de schamele uitrusting, hun door de zielverkoopers verstrekt, bestond meestal uit niet veel meer dan een paar hemden, een hoed, een pijrok, een of twee paar schoenen, twee paar kousen, een paar slaapmutsen, twee linnen kamizolen en twee linnen broeken. ${ }^{2}$

Ofschoon de artikelbrief voorschreef dat de militairen evengoed bij de kwartieren moesten worden ingediend als het bootsvolk "om elk haar wacht te bewaren, te roer en te waak te gaan en voorts ook, niet alleen als de nood zulks vereischte maar ook wel altemet buiten nood, alle scheepswerk te doen» opdat zij zoowel tot den zee- als tot den landdienst bekwaam zouden worden,$^{3}-$ in weerwil, zeg ik van die bepaling schijnt hetgeen de soldaten aan boord verrichtten volgens een schrijver van de tweede helft der $17^{\mathrm{e}}$ eeuw toentertijd uit weinig meer te hebben bestaan dan uit exerceeren, voor de kajuit en konstapelskamer op schildwacht staan, "een touwtje achter de hand halen ", nu en dan bij hard weder, want anders waren zij er vrij van, aan de roertalies den roergang waarnemen en op de retourreis, want op de uitreis waren zij er niet toe verplicht, op den uitkijk staan. ${ }^{4}$ In hoofdzaak kwam het scheepswerk neer op de schouders van de matrozen, die daar trouwens ook de meeste geschiktheid voor bezaten. $Z_{i j}$ laadden en losten de schepen, sloegen de zeilen af en aan, teerden en reinigden het schip, kalefaatten de naden van het dek, schraapten van tijd tot tijd de groente en de schelpdieren af, welke zich aan den buitenkant van het schip hadden gehecht en den voortgang vertraagden ${ }^{5}$, sponnen schiemansgaren, vlochten servings, ${ }^{6}$ moesten het oude

1 Cornelius de Jong, Reizen naar de Kaap de Goede Hoop enz. in de jaren 1791-1797, Haarlem 1802, II blz. 155 vlg. - Volgens Witsen echter, a. w. blz. 405, mocht niemand van het gemeene volk zich des nachts ontkleeden of zelfs zijn schoenen uittrekken.

2 Langhansz, a. w. S. 17; Veirac, a. w. blz. 21.

3 Artikelbrief 1634, 1658, 1672 en 1742 resp. art. 128, 107, 107, 113.

4 De Graaff, a. w. blz. 30.

5 Oudtijds geschiedde dit met een driehoekigen ijzeren schrabber (Barchewitz, a. w. S. 77), naderhand met een uit borstels samengesteld werktuig, de "hog" genoemd, waarvan een afbeelding voorkomt in Cornelis Pietersz., Practicale Stuurmanskunst, Amsterdam 1791, blz. 197.

6 Dat is: touwwerk, dat tot bedekking diende. 
touwwerk uitpluizen of "ganzen plukken» zooals het in de wandeling heette, om daar als het eenige dagen lang in water te weeken gelegen had lijnen en strikken van te draaien, van tijd tot tijd het buskruit keeren, brandhout en water van den wal halen, in één woord op den minsten wenk van de bevelhebbers gereed staan om al wat hun gelast werd zonder morren te verrichten, op straffe van bij de geringste onwilligheid een dracht slagen met het piktouw, de zoogenaamde dagge, te ontvangen. ${ }^{1}$ Tijdgenooten die hun leven en bedrijf op de Compagnieschepen hadden gade geslagen en met eigen oogen getuigen waren geweest van de beestachtige behandeling, hun door de schippers aangedaan, aarzelden dan ook niet hun lot te vergelijken met dat van slaven en het woord op hen toe te passen: "menschen aan den wal, ezels aan boord" 2 .

Dat men onder zulke omstandigheden zoomin van het zedelijk gehalte als van de bekwaamheid der bootsgezellen veel verwachten mocht, ligt voor de hand. Het alle denkbeeld te boven gaande vloeken, schoppen en slaan, dat met hun aanboord komen placht vergezeld te gaan ${ }^{3}$, was slechts een voorlooper als het ware van hetgeen er op de reis zelve zou geschieden. Dieverijen, dikwijls reeds begonnen toen men nog op de reede lag, ${ }^{4}$ plukharen, dronkenschap, muiterijen, om van andere misdrijven te zwijgen, waren somtijds aan de orde van den dag. Niet beter stond het veelal geschapen met hun bekwaamheid. Terwijl men hier te lande voor andere schepen keur van volk kon bekomen, getuigt de advocaat der Compagnie Pieter van Dam, moesten de Oostinjevaarders zich met het uitschot vergenoegen: "veel onbedreven volk, jongens en diergelijke» ${ }^{5}$. En volgens een bericht van 1760 waren er onder de 150 à 160 bootsgezellen, welke toenmaals gewoonlijk op een Compagnies-

1 Journaal uitgaand schip Amsterdam (13 Maart 1635); Witsen, a. w. blz. 416; P. van der Burg, Curieuse beschrijving van verscheijden OostIndische gewesten, Rotterdam 1667, blz. 4; De Graaff, a. w. blz. 30; Tappen, a. w. S. 271; Journaal uitgaand schip Godschalksoord in het scheepsboek van dien bodem.

2 De Graaff, t. a. p.; Langhansz, a. w. S. 17, 26, 27; Von Wurmb en Von Wolzogen, a. w. S. 33.

3 Harger, a. w. blz. 356, 357.

4 Harger, t. a. p.; Von Wurmb en Von Wolzogen, a. w. S. 35. Zie ook mijn opstel: „Zieken en dokters op de schepen der O. I. Compagnie".

${ }^{5}$ Beschrijving der O. I. Compagnie Boek III eap. 22 fol. 444. 
bodem werden aangetroffen, dikwijls geen 60 goede bevaren matrozen, "zijnde de overige maar halve natjes of jonge matrozen, waarvan velen tegen den zwaren arbeid en het ruwe zeeleven nog niet waren opgewassen» ${ }^{1}$, ja op het schip Overhout, dat in het najaar van 1774 uitliep, hadden zelfs de meesten hunner nog nimmer een zeereis gedaan ${ }^{2}$. Voor een deel lag de schuld hiervan aan de bedriegerijen der zielverkoopers. Schier dagelijks, de klacht is van 1767 doch was ruim tachtig jaar vroeger ook al vernomen, schier dagelijks kwamen dezen aan de Bewindhebbers der Kamer Zeeland "te presenteeren en lieten te hunner kamer aannemen bevarene matrozen en welgedresseerde soldaten of andere, die om hare bekwaamheid met de hoogste gage naar proportie van haar bedieninge werden begunstigd, doch in plaats van die aangenomen matrozen, soldaten en andere bestonden zij onervarene en gansch onbedreven personen aan boord te leveren en wel bijzonderlijk matrozens, reden waarom de magistraat van Middelburg zich genoodzaakt vond om haar waarschuwing, in 1680 tegen zulke praktijken gepubliceerd, in 1767 te hernieuwen en de zielverkoopers op zware boete wel strikt te verbieden "eenige matrozen of andere personen aan de Compagnie te presenteeren en onder een gefingeerden naam te laten aannemen en, in plaats van die, andere onervarene onder een verkeerden of anderen naam als op de monsterrol was aangeteekend aan boord te zenden" ${ }^{3}$. "Veelmalen" (lezen wij in een werkje dat een oudgast in 1677 in het licht zond) brengen de zielverkoopers "een zeeman in de gedaante deszelfs bij de Edele Compagnie aan, als hebbende hem een rokje en broek aangetrokken, of een ander, op een loozen naam vertoond, daaruit de heeren niet anders kunnen bemerken, maar als het er op aan komt zoo ziet men hier dat het niet al koks zijn die lange messen dragen, want onder het getal van 100 koppen vindt men ordinaris maar 30 à 40 man die opwaarts willen" 4 . Aan den anderen kant werd het gehalte van het scheepsvolk op laag peil gehouden door de schrielheid,

1 Paulus de Wind, Verhandeling der voornaamste ziekten op de O. I. schepen, Middelburg 1760, blz. 91.

2 Von Wurmb en von Wolzogen, a. w. S. 44.

$s$ Waarschuwing van Burgemeesters, Schepenen en Raden van Middelburg 4 April 1767 (Kol. Arch. $\mathrm{n}^{\circ}$ 8314).

- Van der Burg, a. w. blz. 2. 
waarmede de Bewindhebbers hun dienaren bezoldigden, en die er onder anderen gedurende den Engelsch-Franschen oorlog van 1756-1763 de flinke Deensche en Zweedsche zeelieden toe bracht om, in plaats van bij de Compagnie, dienst te nemen bij de Engelschen en Franschen, van wie zij hooger soldij konden bedingen ${ }^{1}$.

Bijna altoos was de bemanning voor een deel, en dikwijls een aanzienlijk deel, samengesteld uit vreemdelingen ${ }^{2}$. De Bewindhebbers mochten in den eersten tijd van de Compagnie al bepalen dat men geen Oosterlingen ${ }^{3}$ en Noren, veelmin Franschen, Engelschen of Schotten zou aannemen ${ }^{4}$, het enorme verbruik van menschenmateriaal, om zoo te spreken, zoowel op de schepen als op de comptoiren in Indië ${ }^{5}$, maakte op den duur alle verordeningen van dien aard tot een doode letter: zoolang de Compagnie heeft bestaan vertoonde de bevolking van haar schepen een bont mengelmoes, uit aller heeren landen saamgevloeid. Over de vraag of dit al dan niet in het belang van den dienst moest worden geacht, werd verschillend geoordeeld. De meesten, verzekert ons de bekende Nicolaas Witsen - hijzelf behoorde daar ook toe trouwens - zagen er geen bezwaar in, vonden het zelfs gewenscht omdat op bodems, waar volk van verschillenden landaard bijeen was, minder gevaar bestond voor "samenrottingen». ${ }^{6}$ Toch bracht het zijn eigenaardige moeilijkheden mede. Ziehier bijvoorbeeld wat Jacques Specx wedervoer, toen hij met de onder zijn opperbevel gestelde uitreisschepen in 1629 voor Duins ten anker lag. Een drietal Engelschen van het schip Frederik Hendrik drosten op een nacht met de schuit naar den wal, en strooiden daar uit dat de Engelschen op de vloot slecht behandeld werden. Kort daarop verscheen de kapitein van een Engelsch koningschip aan boord van de Frederik Hendrik om van den gezagvoerder "met een zeer irreverente en onverdragelijke trotsmoedigheid» al de Engelschen op te eischen, die zich op het schip bevonden, daar hij

1 De Wind, a. w. blz. 91.

2 Blijkens de Scheepsboeken en tal van andere bescheiden.

${ }^{3}$ Dat is: lieden die afkomstig waren van de kusten der Oostzee.

4 Resolutiën Zeventien 14 Febr. 1603, 19 Oct. 1616, 14 Aug. 1617.

s Volgens Müller, a. w. blz. 10, zeide het publiek destijds (in 1668) dat van degenen, die naar Indië gingen, tenauwernood één op de honderd terugkeerde.

6 Witsen, a. w. blz. 404. 
hen, volgens zijn zeggen, noodig had voor den dienst des konings. "Wat discreete excusen» de Hollandsche bevelhebber ook aanvoerde, of hij al verlof vroeg om eerst den admiraal Specx van het geval te verwittigen, het was alles te vergeefs, "daar moesten drie Engelschen per force medegaan". "Daar te voren (schrijft Specx aan de Bewindhebbers) was een ander Engelsch kapitein mede ten zelven fine aan het schip Frederik Hendrik geweest, dien de heer vicekommandeur met een onderkoopman bij ons zond, welken wij door beleefd verzoek en eerlijk onthaal deden desisteeren, hebbende ons niet goed gedacht eenige contestatiën ofte disputen op ons recht of hare autoriteit omme de Engelschen te mogen lichten willen moveeren, zoolange met zoetigheid het onze kunnen behouden» ${ }^{1}$. Ook in later tijden, inzonderheid wanneer Engeland in een oorlog was gewikkeld, is het herhaaldelijk voorgekomen dat Britsche officieren van Compagniesschepen, bij Duins, Portsmouth of elders voor anker liggende, soldaten en matrozen kwamen afhalen, die geboren Engelschen waren ${ }^{2}$. Bovendien leverde het aannemen van vreemd volk nog andere gevaren op. Specx, die op de zaak blijkbaar een geheel anderen kijk had dan Witsen en de zijnen ${ }^{3}$, kan als hij het te Duins voorgevallene aan de Bewindhebbers overbrieft, niet nalaten er het volgende aan toe te voegen: "voorwaar Mijne Heeren 't en is niet zonder groote moeite wanneer men gelijk nu hier inkomen moet, en niet zonder perikel van tsamenrottinge onderwegen of minder moeite en nabedenken in Uw Ed. forten in Indië zooveel en principalijk zulke vreemde natiën in Uw Ed. dienst te nemen, die doch schier of morgen (experientie bekomen hebbende) maar zullen trachten Uw Ed. Staat te helpen contramineeren, gedenkende mij zeer wel hoe dikmaal wij in Indië zijn bekommerd geweest zooveel Engelschen en Franschen onder ons garnizoen te hebben, twelk wij verhopen en verzoeken dat $U$ Ed. in het toekomende gelieven te preveniëeren en Indië met goede, getrouwe Nederlandsche harten voorzien» ${ }^{4}$.

1 Brief van Specx aan de Kamer Amsterdam 14 Feb. 1629.

2 Blijkens de scheepsboeken van de bodems De Standvastigheid 1743/4, Westhoven 1745/6, Ouder-Amstel 1759/61, Aschat 1761/2, Voorland 1761/2, Aschat 1761/2, Het Huis te Bijweg 1762/3.

3 Zie hiervóór.

4 Brief van Specx als voren.

Dl. 69 
Welk gespuis nu en dan onder die vreemdelingen school ziet men uit hetgeen een Bewindhebber van het eerste vierendeel der $17^{\mathrm{e}}$ eeuw, de bekende Arend van Buchell, verhaalt van het in October 1621 uitgezeilde schip De Witte Beer. Daar hadden namelijk eenige opvarenden, allen uit de kuststreken van NoordDuitschland of om met Buchell te spreken "uit den Oosterschen hoek» af komstig, het plan gesmeed om de officieren in de kajuit te vermoorden, degenen die zich niet bij hen aansluiten wilden overboord te werpen, en met het aldus afgeloopen schip koers te zetten naar Schotland. ${ }^{1}$ En nog geen tien jaren waren er. sinds Buchell dit schreef verloopen, toen onder de soldaten op het schip Deventer alweder een complot werd ontdekt om den bodem af te loopen en in handen van de Spanjaarden te spelen. "Meest al deze schelmen (bericht een die op hetzelfde schip medereisde aan de Bewindhebbers) zijn Paapsch of Luthersch geweest, zoodat UEd. in het toekomende op dezelve te letten heeft en UEd. gerecommandeerd zij zoo weinig Duitschen aan te nemen als mogelijk is, want dezelve een ongebonden hoop is, daar vele meineedige moorders, roovers en andere vagebonden onder loopen, ${ }^{2}$ gelijk wij er vele op ons schip gehad hebben dat ik het mij schamen zou te schrijven». ${ }^{3}$ Ook hij was blijkbaar de meening toegedaan dat men zooveel doenlijk landgenooten in dienst behoorde te nemen. "Zoo UEd., wanneer het tegen den tijd gaat, in onze provinciën en principale steden den trommel * laat slaan (zegt hij) 't en zal ons aan geen bekwaam volk gebreken, maar dan zal men zich aan geen acht ofte veertien

1 MS. Aanteekeningen van Arend van Buchell, Bewindhebber ter Kamer Amsterdam (1619-1621, folio 51 recto.

2 Gunstiger werd door sommigen over de Engelschen geoordeeld. „Tot nog toe (schrijft Gerard Reijnst op 25 Januari 1619 uit het schip Amsterdam van vóór Kaap Lopo Gonsalves) heeft men geëxcuseerd Engelschen aan te nemen, dan voortaan zoude raden die niet te excuseeren, want de Engelschen zeer serviabel zijn en in obedientie kunnen gehouden worden, die hen ook ordinairlijk fraai in 't habijt houden."

s Op het schip Nieuwerkerk, in 1745 uitgeloopen, smeedden de Franschen aan boord, ten getale van meer dan 50 , in de Spaansche zee een complot met de Duitschers om, terwijl een hunner voor de kajuit de wacht hield, daarin te vallen, de wapens te vermeesteren, alle officieren, behalve één stuurman, en allen die niet met hen wilden samenspannen te vermoorden, en schip en lading te verkoopen. Het plan lekte uit door een twist, wie den eersten aanval zou doen; zie de sententiën in het Scheepsboek van gemeld sehip.

Dat is: den werftrommel. 
dagen moeten binden alsook de schippers bij tijds aannemen en haar last geven naar bekwaam volk om te hooren, die zij kennen en weten waarvandaan zijn, bij dewelke UEd. vooreerst het aanritsgeld ${ }^{1}$ zullen profiteeren en UEd. schepen geen perikel loopen, zoo al schoon een gulden of anderhalf meer moet geven. ${ }^{2}$

Helaas onder de Nederlanders zelven, die voor den dienst in Indië uitkwamen, waren de "goede, getrouwe harten» maar al te zeldzaam. Reeds in 1614 sprak de Gouverneur Generaal Pieter Both de bitterste klachten uit over het geboefte, dat uit het Vaderland derwaarts werd gezonden: bankroetiers, ${ }^{3}$ lieden die het door "kwade menage» niet langer aan den vasten wal konden uithouden, krijgsvolk dat bij den vijand had gediend en dergelijken.» Het schijnt (dus klaagt hij) dat het land van ervaren landzaten gepriveerd is. Men brengt er in de schepen, sommigen met de boeien aan de beenen om herwaarts te komen, van anderen wordt den schippers belast haar aan land niet meer te laten komen, eenigen geheel van haar verstand beroofd en alzoo onbekwaam tot eenigen dienst. Het is een gruwel alhier om te zien, wanneer de schepen aankomen, van haar dissoluut leven. Wij hebben dagelijks alhier genoeg te doen haar te hoeden om het drinken te beletten, en is nochtans niet mogelijk, hoe scherpe opzicht wij hebben, voor te komen, en alsdan vechten, de Chineezen slaan en berooven haar geweld aandoende, waaruit klaarlijk is blijkende dat de meeste vagebonden en het schuim van het Vaderland hier komt» ${ }^{4}$. En zoo bleef het voortdurend, voornamelijk wat de uitgezonden soldaten betrof, onder wie zich, gelijk de Heeren Zeventien in April 1618 zelf bekennen moesten, "sommaals eenige gedebaucheerde kwanten» bevonden, "die ofte alhier gefailleerd waren ofte hun anderszins groffelijk hadden verloopen» 5 . Wat naar Indië gaat, alzoo was

1 Dat is: handgeld.

2 Brief van Artus Gijsels aan de Kamer Amsterdam uit het schip Deventer liggende in de Tafelbaai, 6 Sept. 1630.

${ }^{3}$ Het meest illustre voorbeeld van zoo'n bankroetier, die naar Indië ging, is de Gouverneur-Generaal Antonio van Diemen geweest, die in 1618 als adelborst van het schip Mauritius onder den naam van Tonis Meeuwsen (zijn vader heette Bartholomeus van Diemen) uitkwam, zie L. C. D. van.Dijk, Nederland's vroegste betrekkingen met Borneo enz., Amst. 1862, blz. 87, 385.

4 Brief van Pieter Both aan de Bewindhebbers uit Bantam 10 Nov. 1614.

${ }^{5}$ Brief van de Zeventien aan den Gouverneur-Generaal Jan Pieterszoon Coen 10 April 1618. 
klaarblijkelijk de gansche $17^{\mathrm{e}}$ eeuw door de publieke opinie, is niet anders dan slecht volk, dat nergens toe deugt of door wangedrag zijn fortuin heeft zoek gemaakt '

Veel talrijker dan onder de zeevarenden, die gemeenlijk twee derden van de bemanning uitmaakten, ${ }^{2}$ was naar verhouding het niet-nationale element vertegenwoordigd onder het overige derde deel, de soldaten. In Januari 1622 bevonden zich onder de 143 soldaten van het garnizoen te Batavia niet minder dan 60 Duitschers, Zwitsers, Engelschen, Schotten, Ieren, Denen en andere vreemdelingen ${ }^{3}$. Een oud reisbeschrijver beweert zelfs, maar dit is blijkens de monsterrollen van dien tijd een schromelijke overdrijving, dat omstreeks 1710 de militie te Batavia nagenoeg geheel uit Duitschers, Zwitsers en Polen bestond en nauwelijks 10 Hollanders telde. ${ }^{4}$ Afgezien trouwens van zulke vreemdelingen, welke van den honger of uit vrees voor den arm der justitie binnen onze landpalen werden gedreven en op het laatst ten einde raad de prooi werden van de zielverkoopers, lag er zelfs voor uitlanders, op wier. karakter en begaafdheid niets viel af te dingen en die in de Oost hun geluk wilden beproeven, geen andere weg open dan dat zij bij de Compagnie als soldaat in dienst traden. Voor bedieningen toch van aanzien plachten zich bij de Bewindhebbers veel meer gegadigden aan te bieden dan men behoefde, zoodat alleen zij daar toe werden aangesteld, die welervaren waren in den koophandel of den steun genoten van veelvermogende bloedverwanten of vrienden. ${ }^{5}$ In Indië aangekomen, zochten

1 Müller, a. w. blz. 10; Van den Burg, a. w. blz. 3; De Graaff, a. w. blz. 24, 25.

"Zie de opgaven in het "Notitieboek van Compagnies uitgeloopen schepen" over 1724-1742; De Wind, a. w. blz. 91.

s Blijkens de monsterrol van 22 Januari 1622 . Bij deze 60 vreemdelingen zijn niet medegerekend 17 personen geboortig uit de Zuidelijke Nederlanden, en 9 waarvan de herkomst onzeker is. Op het fort Saboegoe op Halmaheira lagen blijkens de monsterrol over 1618-1620 behalve soldaten van Noorden Zuid-Nederlandsche herkomst en Indische militairen ook soldaten uit Emden, Bremen, Hamburg, Hitland (Shetlandseilanden) en Schotland. Op het in 1635 uitgezeilde schip Amsterdam bevonden zich blijkens de monsterrol militairen uit Duitschland, Frankrijk, Ierland, Denemarken en Noorwegen. Evenzoo Engelschen, Schotten en Ieren in het fort aan de Kaap in 1660 , zie Saar, a. w. S. 159.

4 Johann Gottlieb Worms, Ost-Indianische und Persianische Reisen, Dresden en Leipzig 1737, S. 93.

5 Frikius, Hesse en Schweitzer, a. w. blz. 9. 
zulke vreemdelingen in den nederigen post van "soldaat aan de pen» bij de negotie te worden geplaatst ${ }^{1}$, waar zij allengs hooger opklimmende somtijds, zoo het lot hun gunstig was, de hoogste sporten van de ambtelijke ladder bereikten, getuige om geen minderen te noemen het voorbeeld van Johannes Thedens, een geboren Duitscher, die zijn loopbaan als soldaat begon en als Gouverneur-Generaal eindigde.

Ofschoon eigenlijk alleen medevarende om op de plaats hunner bestemming te komen, konden strikt genomen de soldaten toch niet als passagiers worden aangemerkt. Niet alleen dat zij de matrozen, zooals wij reeds zagen, in hetgeen er op de wacht te verrichten viel hadden bij te staan, zij moesten ook in tijd van nood schip en lading helpen verdedigen tegen vijanden of zeeroovers, tegen de gevreesde Algerijnen in het bijzonder, welke zich in de $17^{\mathrm{e}}$ eeuw gewoonlijk in de buurt van de Scilly-eilanden ophielden ${ }^{2}$ maar in sommige jaren tot voor de monden van de Schelde en de Maas en tot bij Texel toe op onze koopvaarders jacht kwamen maken ${ }^{3}$. Zoodra de man op den uitkijk zulk een vijandelijk schip had gesignaleerd, kwam de geheele bemanning in rep en roer. De soldaten haalden hun snaphanen, stormhoeden en zijdgeweer, de matrozen hun kromme sabels voor den dag ${ }^{4}$, er werd op den overloop zout gestrooid om des te vaster te staan, men plaatste het volk deels bij de stukken van het geschut, stelde een ander deel aan om de zeilen te schaveelen en kardoezen en ammunitie aan te dragen, bekleedde de marsen en het schip met schanskleederen om dekking te verschaffen aan de manschappen, die den vijand met handgranaten en musketvuur bestookten, bond de raas met ijzeren kettingen vast opdat zij niet werden afgeschoten, men bracht om ruimte te hebben de kisten van het volk op den

1 Van Dam, Beschrijving der O.-I. Compagne, Boek I Deel I eap. 18 fol. 418 vlg. Vgl. ook Von Wurmb en Von Wolzogen, a. w. S. 6.

2 Gijsbert Heecq, Derde Voyagie naar Oost-Indyen (ed. S. P. l'Honoré Naber in Het Marineblad 1910/11).

3 J. C. de Jonge, Gesehiedenis van het Nederlandsche Zeewezen, Haarlem 1858 vlg., III, blz. 33.

4 Blijkens het journaal van het uitgaand schip Het Wapen van Amsterdam deelde men op 13 Mei 1614, toen het ter hoogte van Bevesier en Wight kwam, „aan de soldaten een musket, forketstok, stormhoed, zijdgeweer en bandelier, en aan de matrozen een musket en sabel" uit. De forketstok was een soort van gaffel, waarop het musket bij het afvuren rustte. 
overloop of wierp ze over boord, plaatste brandende lonten bij het geschut, bracht handgranaten, enterbijlen, stinkpotten, degens, sabels, pistolen en geweren boven, vulde de bandeliers en kardoezen en zette van deze laatste een voldoenden voorraad bij de kanonnen, men zorgde dat op den overloop hier en daar "ijzeren hoepen of vierkante houten baks tot de kardoezen en zooveel rond-, lang- en scherp schroot en lantarens werden verdeeld" als men rekende noodig te zullen hebben, smeerde de wielen en assen van de ropaarden of affuiten van de kanonnen glad, zette tusschen de stukken, op de marsen en elders waar het te pas kon komen waterbalies, pudsen en natte zwabbers klaar zoo om de stukken te koelen als om elk begin van brand te kunnen blusschen, en deelde voor de strijd zou aanvangen aan de manschappen een dronk wijns uit om hun moed te geven. Onder het gevecht reikten de ziekentrooster en wie er al meer tot vechten onbekwaam waren uit de kruitkamer het buskruit aan, terwijl de chirurgijns onder in de kombuis of in de bottelarij de gekwetsten zaten te verbinden, en eenige jongens met hun ééne oor plat tegen het dek lagen scherp toeluisterend of het schip ook ergens onder de waterlijn van een vijandelijk schot werd doorboord, opdat de scheepstimmerlieden, die met proppen, platloode platen en ander materieel gereed stonden, het lek aanstonds zouden kunnen dichten ${ }^{1}$. Van het grootste belang was het nu dat men den wind tot zijn voordeel zocht te krijgen zoodat de kruitdamp naar de zijde van den vijand toe dreef en hem het uitzicht belemmerde. In dit geval kon men des te gemakkelijker de gevaarlijke branders, welke hij afzond, met krachtig vuren en het uitzetten van gieken van zich af houden of wel ze tegen zijn eigen schepen aanjagen opdat deze van de haken, die aan de raas van de branders hingen, in het want werden gegrepen en zoodoende in brand zouden vliegen. Niet minder gevaarlijk, ja noodlottiger zelfs dan de door alles heen borende kanonkogels waren bij een zeegevecht de overal rondvliegende splinters van de stukgeschoten rondhouten, (masten, raas, stengen, sprieten enz.), die de manschappen de ijselijkste verwondingen en kwetsuren toebrachten. Slaagde de vijand er trots allen tegenweer in om het schip te

1 Journaal uitgaand schip Zutphen (18 Juni 1632); Breederaadresolutie uitgaande schepen Banda, Middelburg enz. (10 Maart 1636); Müller, a. w. blz. 1 vlg.; Witsen, a. w. blz. 404, 405, 411; Tappen, a. w. S. 272. 
enteren, dan werden de deuren van de kampanje en den bak gesloten, en poogde men hen van daar uit met kanonvuur te doen afdeinzen, wanneer ook dit mislukte bleef er niets anders over dan dat men zich overgaf of zich beneden in het schip terugtrekkende met steken en schieten den strijd op leven en dood voortzette. ${ }^{1}$

Poogde men bij het volk den moed aan te wakkeren door hun vóór het gevecht als hartsterking een dronk wijns te schenken, ${ }^{2}$ een ander middel, waarmede men het tot dapperheid prikkelde, was de belofte van een aandeel in den te behalen buit. Van alles wat wettelijk voor goeden prijs werd verklaard, zoo bepaalden de artikelbrieven van 1634, 1658 en 1672, moest eerst worden afgetrokken een vijfde als gerechtigheid voor het land, een dertigste voor hetgeen den Prins van Oranje als admiraalgeneraal toekwam ${ }^{3}$, en bovendien zooveel als benoodigd was tot vergoeding van de onkosten, «in het beneficeeren van de veroverde goederen gemaakt» en van de schade geleden door "het schip of schepen, daarmede de prijzen veroverd waren»; van hetgeen er daarna overschoot genoten allen, die tot het vermeesteren van den buitgemaakten prijs hadden medegeholpen, den zestienden penning of $6 \frac{1}{4}$ procent. $4 \mathrm{Bij}$ den artikelbrief van 1742 , die op dit stuk duidelijker en uitvoeriger is dan zijn voorgangers, werd de zaak op de volgende wijze geregeld. Wanneer op de eerste "hoofdplaats» van de Compagnie, welke men bezeilen kon, in rechte was uitgewezen dat het veroverde als wettig verkregen buit was te beschouwen, moest, na aftrek van de kosten en een vijfde part voor de gerechtigheid van het gemeene land ${ }^{5}$, worden toegelegd "een zestiende van het overige aan het volk tot buitgeld, ieder prorato van de bezoldinge, die hij won, mitsgaders van het verdere overschot $\frac{1}{3}$ aan den kapitein, schipper of gezagvoerder, $\frac{1}{3}$ aan de opperofficieren te zamen, en het laatste $\frac{1}{3}$ aan de Compagnie voor het hazard, de kosten en reparatie van haren bodem; de deks- en onder-

1 Tappen t. a. p.

2 Witsen a. w. blz. 404.

3 In 1658 , toen er onder de stadhouderlooze regeering geen admiraal-generaal was, verviel ook dit dertigste an het land, zie den artikelbrief van 1658 art. 43.

4 Artikelbrieven 1634,1658 en 1672 resp. art. 50, 43 en 43.

- Van een aandeel voor den admiraal-generaal wordt wegens het stadhouderloos bestuur niet gewaagd. 
officieren pro rato harer maandgelden nevens het volk in het buitgeld deelende; en de fiscaal van de plaatse, alwaar daarover geprocedeerd worden zou, nevens de beide luitenants in het derde deel der officiers ieder voor $\frac{1}{4}$ mitgaders de opperstuurman voor $\frac{1}{8}$ en de onder- of mindere stuurlieden te zamen voor $\frac{1}{8}$ haerideerende. 1

Ten aanzien van de gage was door de artikelbrieven verordend, dat zij inging zoodra de schepen "buitenduins» of "buitengaats k kwamen en eindigde wanneer de manschappen werden afgedankt ${ }^{2}$. Voor het werk, dat zij gedurende het verblijf op de reede vóór het uitzeilen verrichtten, genoten zij geen loon ${ }^{3}$, althans in den regel niet want uit sommige scheepsboeken blijkt, dat de soldij voor dezen en genen begon te loopen van het oogenblik af waarop zij aan boord kwamen ${ }^{4}$. Zeldzame gevallen uitgezonderd, waarin òf drie òf vier maanden of ook wel niets werd gegeven ${ }^{5}$, ontving elk schepeling, als hij in dienst trad, twee maanden gage op de hand. Voor de soldaten voegde de Compagnie, bij schaarschen toeloop van militairen, daar in de $17^{\mathrm{e}}$ eeuw soms nog als "heerengift» een extra-gift bij van twaalf of vierentwintig stuivers ${ }^{6}$, terwijl hun verder de geheele $17^{\mathrm{e}}$ eeuw door geregeld voor «kost-, serviesof loopgeld» een dagelijksche toelage werd geschonken van zes stuivers, te rekenen van het oogenblik hunner aanneming af totdat zij met lichters naar boord van de schepen vertrokken ${ }^{7}$. $\mathrm{Nu}$ en dan gaf men zulk een toelage ook aan de matrozen; zoo bijvoorbeeld in Maart 1692 toen de Bewindhebbers wegens

1 Artikelbrief 1742 art. 50, 51.

2 Artikelbrieven voor de vloot van Jacob van Heemskerk in 1601, van 1634, 1658,1672 en 1742 art. resp. $7,34,34,34$ en 35 .

3 Langhansz, a. w. S. 33.

4 Scheepsboeken uitgaande bodems Anna 1742, De jonge Lieve 1761, Ouwerkerk 1783, Dordrecht 1789. Vgl. ook Res. Zeventien 22 April 1779, waar uitdrukkelijk wordt gezegd dat de gage bij sommigen placht in te gaan, nadat het schip buitengaats was gekomen, en bij anderen zoodra het volk aan boord kwam.

- Scheepsboeken uitgaande bodems Vosmaer 1704, Scheijbeek 1748, De jonge Lieve 1761 .

6 Van Dam, a. w. Deel I Boek I eap. 18 fol. 398, 399. - Of het ook in de $18^{\circ}$ eeuw plaats had blijkt niet.

7 Artikelbrieven van $1619,1634,1658,1672$ resp. art. 121, 125, 105, 105; Saar, a. w. S. 2; Daniel Parthey, Ost-Indianische und Persianische neunjährige Kriegsdienste, Nürnberg 1698, S. 7. In den artikelbrief van 1742 wordt van geen loopgeld meer gerept. 
het gebrek aan volk aan ieder, die zich voor matroos aanmelden zou, een loopgeld toezegden van acht stuivers daags, en tegelijkertijd dat van de soldaten, voor het geval men ook dezen moeilijk mocht kunnen verkrijgen, van zes tot acht stuivers verhoogden ${ }^{1}$. Twee jaar later ging het bemannen van de schepen met zooveel bezwaren gepaard, dat de Zeventien de Kameren machtiging moesten verleenen om aan alle matrozen, die tien gulden of meer in de maand trokken, boven en behalve de acht stuivers loopgeld nog een maand gage tot een vereering toe te leggen ${ }^{2}$. Omstreeks 1776 was zelfs het gebrek aan volk zoo nijpend dat de Kameren van de Vergadering van Zeventien verlof bekwamen om aan "zware» zeevarenden vier en aan jonge drie maanden op de hand te verstrekken, met bevoegdheid om, indien ook dit niet baten mocht, daar een extra-premie aan toe te voegen tot een maximumbedrag van tien en een halven gulden voor een matroos die tien, van veertien gulden voor een die elf, en van achttien gulden voor een die twaalf gulden in de maand verdiende ${ }^{3}$. De gages zelve beliepen gedurende de $17^{\mathrm{e}}$ eeuw maandelijks voor de busschieters, dat is voor die bootsgezellen welke den konstapel of scheepsartilleriemeester bij de verzorging van de ammunitie en het geschut hielpen, van zeven tot twaalf gulden, voor de matrozen van zeven tot elf, voor de jongmatrozen zes of zeven, voor de hoop-, op- of inloopers (halfwassen brasems van 16 tot 18 jaar oud die mannenwerk verrichtten ${ }^{4}$ ) vijf, zeven, acht, negen of tien, voor de scheepsjongens vier of vijf en voor de soldaten zeven, negen of elf gulden ${ }^{5}$. In de $18^{\mathrm{e}}$ eeuw verdienden de busschieters een maandgeld van negen tot zestien, de matrozen een van zeven tot zestien of ook wel van twintig gulden, de jongmatrozen een van zeven of acht, de hooploopers een van zes, zeven of acht, de jongens een van vijf of zeven en de soldaten een van negen gulden ${ }^{6}$.

1 Res. Zeventien 24 Maart 1692. Soortgelijke bepalingen in resolutiën Zeventien 4 Nov. 1692, 27 Oct. 1693.

2 Res. Zeventien 12 Aug. en 4 Nov. 1694.

s Res. Zeventien 4 Nov. 1776.

- Witsen, a. w. blz. 417.

${ }^{5}$ Blijkens de opgaven van het uitgaande schip Ámsterdam 1634, en de scheepsboeken der uitgaande bodems Nassou 1635, Olifant 1648, De Betuw 1674, Nederland 1699.

- Blijkens de scheepsboeken der nitgaande bodems Ellemeet 1700, Drechterland 1700, Driebergen 1700, Reigersdaal 1700, Castricum 1724, Het Hof 
Voor de uitbetaling van de gages gold sedert 1646 de regel, dat zij geschieden moest door die Kamer voor welke men was uitgevaren ${ }^{1}$. In Indië mocht zoowel op hetgeen gedurende de uitreis als op hetgeen daar te lande zelf verdiend was niets worden afbetaald zonder speciaal verlof van genoemde kamer ${ }^{2}$, en nooit meer dan drie of uiterlijk vier maanden gage in één jaar, behalve aan de soldaten en matrozen, die aan land werden. gebruikt, welke "naar gelegenheid van ieders behoeftigheid" iets meer mochten ontvangen doch op zijn hoogst slechts zes maanden, alles teneinde er op hun rekeningen genoeg zou overblijven om aan vrouwen of anderen in het Vaderland de bij hun maandbrief besproken uitkeeringen te kunnen doen, zonder dat de Compagnie daar bij te kort kwam ${ }^{3}$. Bij den artikelbrief van 1742 werd deze regeling, "opdat de dienaren van de Compagnie aan haar bezoldinge inmiddels eenige subsistentie mochten vinden», in zooverre gewijzigd dat allen, die nog in hun eerste verband dienden en niet te kwaad bekend stonden, één maand gage bij de Compagnie konden bekomen, waarvoor zij dan op hun rekening zouden worden gedebiteerd, uitgezonderd alleen zij, die intusschen in het huwelijk waren getreden en op hun

Niet altijd Zomer 1724, Het Land van Belofte 1724, Padmos 1724, Goudriaan 1725, Sparenrijk 1749, Nieuw Vijvervreugd 1749, Osdorp 1750, Oostkappel 1750, Nieuwstad 1750, Bartha Petronella 1772, Popkensburg 1775, Hoolwerf 1775, De jonge Samuel 1774, Abbekerk 1774, Juno 1775, Buiten Verwachting 1794, Voorland 1794, Makassar 1793, Teijlingen 1792, Blitterswijk 1790 en Siam 1793. Zie verder de reglementen op de gages van Maart 1649, November 1692; De Graaff, a. w. blz. 31.

De voor matrozen hooger loopende gages dan twaalf gulden per maand schijnen echter slechts nu en dan te zijn uitgeloofd als er moeilijk te verkrijgen waren. Bij resolutie Zeventien van 22 April 1779 werd namelijk besloten dat "tot een preuve om den toeloop van volk zooveel mogelijk aan te wakkeren" de gages van tien, elf en twaalf gulden bij provisie met vier gulden zouden worden verhoogd, doch die van negen gulden en minder, alsmede die van de soldaten werden op den ouden voet gelaten, met dien verstande echter dat aan matrozen van negen gulden en soldaten een premie zou worden gegeven van drie dukaten. Bij resolutie Zeventien van 24 Mei 1793 werd, al weder wegens het groot gebrek aan manschappen, besloten om "bij provisie tot het volgende voorjaar" de maandgelden van de matrozen van tien, elf en twaalf gulden met vier gulden te verhoogen en die van de manschappen der pakketbooten op zeventien gulden te brengen.

1 Res. Zeventien 15 Aug. 1646.

2 Artikelbrieven van $1634,1658,1671$ en 1672 art. resp. 35, 35, 35 en 36.

s Plakkaat van Gouverneur-Generaal en Raden van 14 Juni 1631; artikelbrieven van 1658 en 1672 art. resp. 36 en 36; res. Zeventien 21 Juni 1700. 
rekening niet te kwaad stonden, "dewelke met alle anderen, die haar eerste verband hadden uitgediend, hare bezoldinge maandelijks zouden mogen ontvangen op dien voet als reeds bij de Compagnie gebruikelijk was». ${ }^{1}$ "Doch (werd er verder bepaald) degenen, die honderdenvijftig guldens ter maand wonnen», met uitzondering alleen van eenige hooge ambtenaren, "zouden zoowel de minsten als de meesten altoos drie jaren van haar bezoldinge bij de Compagnie moeten laten staan, zooals dat albereids ook van over vele jaren in praktijk was geweest». ${ }^{2}$ Uitermate nadeelig voor de dienaren in Indië was de voet, waarop daar te lande van oudsher de betaling van de gages plaats had. "Dewijl namelijk de Compagnie (aldus Van Dam) de gelden daartoe vereischt wordende hiervandaan moet zenden met veel kosten, interessen en perikelen, en dat dezelve daar veel waardiger zijn als hier te lande, wordt die gedaan in licht geld, makende acht schellingen of vierentwintig dubbele stuivers een rijksdaalder van zestig stuivers, welke rijksdaalder het volk wordt aangerekend tegen vierenzestig stuivers en waarvoor zij op hare rekeningen worden belast, voor en in plaatse van die acht schellingen of vierentwintig dubbeltjes die zij ontvangen, en worden de voorschreven vier stuivers op ieder rijksdaalder, voor zooveel die in geld worden betaald, jaarlijks aan winst en verlies goedgedaan ${ }^{3}$. In andere woorden uitgedrukt: terwijl iemand, die een rijksdaalder ontving, maar een waarde van f 2.40 in handen kreeg, werd hij daar op zijn rekening voor gedebiteerd met niet minder dan $f 3.20$. Natuurlijk was deze manier van doen niet zonder murmureering van de belanghebbenden ingevoerd - zij zagen er een onrechtvaardigheid in die regelrecht indruischte tegen den artikelbrief maar door den tijd had het gebruik een vaste plooi aangenomen. Als om de zaak nog erger te maken, deed de Compagnie de uitbetaling slechts voor de helft in specie. De wederhelft werd namelijk voldaan in goederen, en dat wel, zooals een anonieme memorie van omstreeks 1751 bericht, in zoodanige goederen, 'welke bij verkoop de gewone of gefixeerde advancen ${ }^{4}$ niet konden afwerpen» en die bovendien "nog gecargeerd werden

1 Artikelbrief 1742 art. 37.

2 Als voren art. 38.

s Van Dam, a. w. Boek III cap. 14 fol. 240 vlg.

4 Winsten. 
met vijftig procento advance, zijnde de ordinaris winste, waarmede de Compagnie de meest winstgevende koopmanschappen in den Kleinen Winkel en in allen contanten verkoop alomme aan een iegelijk debiteerde», zoodat zij bij verkoop door degenen, die ze in betaling hadden ontvangen, op verre na den prijs niet opbrachten tot welken zij hun waren aangerekend. ${ }^{1} \mathrm{Op}$ het laatst van de $17^{\mathrm{e}}$ eeuw achtte men, dat de Compagnie langs dezen weg een winst maakte van drieëndertigeneenhalf procent op het geld en door de bank een van vijfenzeventig procent op de goederen. ${ }^{2}$ Alles te zamen genomen zou zij, volgens de hiervóór aangehaalde memorie van het midden der $18^{\mathrm{e}}$ eeuw, destijds "op het afbetalen van haar dienaren in Indië permanent honderdveertig en een derde procent » hebben geprofiteerd en daar wederkeerig voor de dienaren een verlies tegen over hebben gestaan van ruim negenendertig procent. ${ }^{3}$ Wie in het Vaderland terugkeerde kon aldaar op zijn medegebrachte rekeningen geen voldoening bekomen tenzij degenen, die van wege Gouverneur-Generaal en Raden met dit werk waren belast, ze met de boeken te Batavia vergeleken en goedgekeurd hadden ${ }^{4}$. Zoo echter de rekeningen door de verdieners uit Indië over werden gezonden, moest de betrokken Kamer eerst zekerheid hebben dat zij hun diensttermijn of zoogenaamde "verband" hadden uitgediend. "Was aan die voorwaarde voldaan, dan mocht op hun order en tegen overlegging van een schriftelijke volmacht aan hun huisvrouw, kinderen of andere vrienden betaling volgen ${ }^{6}$. Hetzelfde mocht gebeuren ten aanzien van de gage, welke iemand op zijn uitreis had verdiend, zoodra men hier te lande tijding had bekomen dat de bodem, waarop hij uitgevaren was, ter plaatse zijner bestemming was aangeland, "mits nevens de schriftelijke last, verzoek of procuratie overzendende de rekening of ander genoegzaam bescheid, wat hem gedurende den eersten verbonden tijd of de uitreize per rest zijner verdiende maandgelden was competeerende». ${ }^{\text {? }}$

1 Aanmerkingen over den jegenwoordigen toestand der generale Nederlandsche O. I. Compagnie in Indiën (Papieren Radermacher).

2 Van Dam, t. a. p.

3 Aanmerkingen over den jegenwoordigen toestand enz.

4 Res. Zeventien 15 Aug. 1646.

${ }^{5}$ Res. Zeventien 5 Dec. 1642 en 9 Nov. 1647.

${ }^{6}$ Artikelbrieven van 1658,1672 en 1742 , art. resp. 34, 34 en 35.

7 Als voren. 
Beliep zijn tegoed dan op de hier te lande berustende boeken te weinig, zoo werd het ontbrekende gedeelte door de Compagnie bijgepast op afkorting van hetgeen hij bij de volgende boeken zou blijken te goed te hebben. ${ }^{1}$ De maandgelden van hen, die vóór het eindigen van hun verband in Indië kwamen te sterven, werden zoodra hun rekening in het Vaderland was overgekomen voldaan aan hun kinderen of erfgenamen ${ }^{2}$, en dat wel in "zwaar geld», dat is de rijksdaalder gerekend tegen vijftig stuivers. ${ }^{3}$ Van hen, die van Nederland uitgevaren zijnde op de uitreis of in Indië stierven zonder erfgenamen, vervielen de verdiende gages en verdere nagelaten goederen aan de Comhagnie ${ }^{4}$. Uitdrukkelijk was tevens door de Zeventien bepaald dat van de in Indië vertoevende Compagniesdienaren geen andere obligatiën, transporten of schulden mochten worden uitbetaald, noch geheel noch gedeeltelijk, dan alleen die met welke zij bij hun vertrek uit het Vaderland belast waren, en insgelijks dat de Kameren aan geen rechterlijke vonnissen, "tot nadeel van zulke personen op derzelver maandgelden gewezen», uitvoering zouden geven maar zich daar in tegendeel tegen verzetten "verstaande de vergadering, dat voor zoodanige crediteurs niet anders open stond als alleenlijk de verdiende of nog te verdienen gages van hare debiteurs in arrest te nemen en daarop derzelver wederkomen of overlijden af te wachten, om alsdan hetzij bij executie of anderszins daarop zoodanig te procedeeren als zij te rade zouden worden». ${ }^{5}$ De reden, die de Bewindhebbers tot deze verordening noopte, was hierin gelegen dat zij de

1 Res. Zeventien 5 April 1697. - Dit had echter ingevolge Res. Zeventien van 30 Maart 1662 geen plaats ten opzichte van de "hooge ministers" in Indië, die ook nà afloop van hun verbonden tijd gehouden waren altijd drie jaar tractement aan de Compagnie te goed te laten.

2 Artikelbrieven van $1634,1658,1672$ en 1742 , art. resp. $38,38,38$ en 39.

3 Res. Zeventien 21 Mei 1670 . Bij deze resolutie werd tevens vastgesteld dat de uitbetaling van de nalatenschap van de in Indië overledenen voor zooveel als zij daarvoor op de soldijboeken werden gecrediteerd voortaan door alle Kameren geschieden zou in licht geld op denzelfden voet als zulks reeds bij de Kamer Amsterdam gebruikelijk was, die vąn zoodanige gelden twintig procent inhield of kortte, "geconsidereerd dat de handel in alle gewesten van Indië gedreven werd in licht geld, dat is de rijksdaalder gerekend tegens zestig stuivers en zoo alle andere speciën naar advenant", en dat bijgevolg de Compagnie hun nalatenschap "ook niet anders als in licht geld ontving".

4 Van Dam, a. w. Boek I Deel I cap. 25 fol. 533.

s Res. Zeventien 2 Mei 1659, 19 Aug. 1671, 12 Mei 1672, 20 Juli 1707. 
Compagnie zoodoende wilden vrijwaren tegen de kans dat zij een en dezelfde maanden in Indië en hier te lande tegelijk en dus tweemaal betaalde. Immers de Compagnie kon niet weten wat en hoeveel zulke debiteurs te goed hadden vóórdat zij thuis kwamen of als vrije luiden uit haar dienst traden, "in voegen dat het dikmaals zoude kunnen gebeuren, dat iemand ten tijde van het doen van zoodanig arrest op de boeken hier te lande een merkelijke somme zouden moeten hebben, die hij ten zelven tijde of te voren in Indië zou kunnen hebben ontvangen». Er kwam bij dat het voor de Compagnie van aangelegen belang werd geacht niet alleen dat haar dienaren gedurende hun afwezen in Indië hier in Nederland niet werden veroordeeld zonder gehoord te zijn, maar ook dat zij aan de Compagnie altoos een goede som te goed bleven opdat men daarop verhaal hebben mocht, voor het geval zij zich in de hun toebetrouwde administratie of in andere zaken te buiten gingen. ${ }^{1}$

Ten strengste was voorts bij de artikelbrieven, op straffe van verbeurdverklaring, verboden zijn rekeningen van verdiende maandgelden te verkoopen of te verpanden. ${ }^{2}$ Toch kwam het maar al te vaak voor dat matrozen en soldaten in Indië, de een uit armoede de ander om aan den wal eens te kunnen uitspatten, al hun rekeningen te gelde maakten. Het misbruik, door baatzoekende individuen hiervan gemaakt, die ze dikwijls voor niet meer dan $\frac{1}{3}$ soms voor slechts $\frac{1}{6}$ van het bedrag der uitstaande vordering opkochten, meestal wanneer de eigenaars beschonken waren, "die alsdan met berooide hoofden en ledige beurzen" in het Vaderland thuis kwamen, noopte de Hooge Regeering in $1636 \mathrm{om}$, in afwijking van een vroeger besluit waarbij het onder zekere voorwaarden was vergund geworden ${ }^{3}$, al zulke transactiën voor goed te verbieden op straffe voor de koopers, verkoopers en "verbandaccepteerders» van confiscatie der gekochte, verkochte en verpande som en een boete bovendien voor de koopers van driemaal zooveel als het saldo der rekening beliep. ${ }^{4}$ Zoo echter iemand in nood verkeerde, stond het hem vrij zijn rekening te verkoopen mits het geschiedde met voor-

1 Res. Zeventien 2 Mei 1659, 12 Mei 1672.

2 Artikelbrieven 1634, 1658, 1672 en 1742 art. resp. 73, 55, 55 en 65.

3 Plakkaat van Gouverneur-Generaal en Raden van 6/9 Sept. 1633, Van der Chịjs, Nederlandsch-Indisch plakaatboek I blz. 297.

4 Als voren 15/20 Sept. 1636, V. d. Chijs, a. w. I blz. 410. 
weten van den opperkoopman, den schipper of de andere opperhoofden, waaronder hij ressorteerde, en het in Indië op de boeken werd ingeschreven. ${ }^{1}$

Van pensioenen, in den hedendaagschen zin van het woord, wist men niet naar het schijnt. Weliswaar werd aan zeevarenden zoowel als militairen, "die buiten debauche of eigen toedoen als afgeleefd waren en geen vermogen hadden om te bestaan» in Indië een zekere maandelijksche toelage verstrekt. ${ }^{2}$ Ook keerde de Compagnie bij wijze van schadevergoeding, als men zoo spreken mag, en volgens een door haar vastgesteld tarief een bepaalde geldsom uit voor het verlies van lichaamsdeelen; zij schonk verder voor alle andere "verlemdheden», waaronder iemand, ofschoon volkomen genezen zijncle, nochtans "van zijn vorige gezondheid beroofd» en "van het vorige gebruik zijner leden » verstoken mocht wezen, een gratificatie, te bepalen «tot discretie van goede mannen ofte doctoren, chirurgijns en anderen hen dies verstaande», altoos indien zij met een verklaring van hun overheid bewijzen konden, dat de kwetsuren waren opgeloopen in het uitvoeren van hun ambt en bediening. ${ }^{3}$

$\mathrm{Bij}$ de maandgelden of gages kwamen voor de gemeene zeevarenden als toevallige baten, behalve het aandeel in den behaalden buit en de roergelden, ${ }^{4}$ bovendien nog vereeringen voor het verrichten van "periculeuse exploiten» ${ }^{\mathbf{5}}$, een maand extra-gage voor het lossen en opbrengen van de retourschepen onverschillig hoe lang het duurde ${ }^{6}$, belooningen voor die het

1 Res. Zeventien 21 Aug. 1629.

2 Van Dam, a. w. Boek I cap. 20 fol. 450. Het bedrag voor de minderen geeft hij niet op.

s Volgens de artikelbrieven van 1622 (art. 34) en 1634 (art. 41) bedroegen de vergoedingen voor het verlies van den rechterarm $f 800$, den linkerarm $\mathrm{f} 500$, één been $\mathrm{f} 450$, de beide beenen $\mathrm{f} 800$, één oog $\mathrm{f} 300$, de beide oogen $f 900$, de rechterhand $f 600$, de linkerhand $f 400$ en de beide handen $f 1000$. $\mathrm{Bij}$ die van 1658 (art. 40), 1672 (art. 40) en 1742 (art. 42) werden zij verhoogd tot $\mathrm{f} 600$ voor één been, $\mathrm{f} 1200$ voor de beide beenen, $\mathrm{f} 400$ voor één oog, f 1200 voor de beide oogen en $\mathrm{f} 1200$ voor de beide handen, doch voor het overige gelaten op den voet als bepaald bij die van 1622 en 1634 .

4 Zie boven blz. 339 en blz. 326.

5 Artikelbrief voor de vloot van Jacob van Heemskerk in 1601, art. 45.

6 Blijkens de Scheepsboeken o. a. van de uitgaande bodems De jonge Lieve 1761, Ouder-Amstel 1759, enz. Volgens den artikelbrief van 1742 art. 42 was het gemeene volk verplicht zoolang op de schepen "te continueeren totdat dezelve geheel ontlost ja zelfs voor de palen of in de havens gebracht waren." 
eerst land in het gezicht kreeg ${ }^{1}$ of een samenzwering aan het licht bracht ${ }^{2}$, alsmede een premie van twee maanden gage zoo, ingevolge de orders van de Bewindhebbers, de thuisreis in plaats van door het Kanaal achter Ierland en Schotland om was gedaan. Naar een reisbeschrijver van het begin der $18^{e}$ eeuw ons mededeelt, geschiedde de vaart "achterom» om tweeërlei reden: in oorlogstijd omdat de retourschepen, wegens hun zware lading uiterst $\log$ in het manoeuvreeren zijnde, gemakkelijk de prooi konden worden van de vijandelijke kapers, die hen in het Kanaal lagen op te wachten; in tijd van vrede omdat de menigte van gedurig aldaar aan- en afvarende schepen van allerlei nationaliteit de bemanning van de retourvloot in de gelegenheid stelde om de door haar medegevoerde verboden goederen van particulieren ter sluiks over te laden of van de hand te doen. ${ }^{3}$ Inderdaad, de schrijver van de reeds meermalen aangehaalde memorie van omstreeks 1751 getuigt het met zooveel woorden, men heeft het bij verscheidene schepen "zien gebeuren dat, in stede van met een favorabelen wind door te zeilen naar de gedestineerde havenen van Nederland, men ter contrarie omtrent de havens van Engeland is blijven tardeeren en sammelen en voor Dover en elders heeft gaan ankeren en een gụnstigen wind laten passeeren, die hen in vierentwintig uren meer en $\min$ in de gedestineerde haven had kunnen brengen, alleen om geen andere oorzaken dan aldaar op te zoeken bekwame gelegenheid om hun medegebrachte particuliere doch ongeoorloofde trafieke in alle veiligheid te debarkeeren;» ja, "andere overheden der retourschepen (hadden) zelfs hen nog wel verder (durven) emancipeeren en die hardiesse geëxtendeerd om zelfs het Verkeerde Kanaal ${ }^{4}$ in te zeilen en in de daar zijnde havenen vijf, zes a zeven maanden of wel zoo lange te blijven liggen tot tijd en wijle zijlieden haren medegebrachten verboden handel in alle veiligheid hebben geconserveerd en bezorgd ». ${ }^{5}$

Verder ontving sedert 1742 elk Compagniesdienaar, die met een retourschip uit Indië terugkeerde, van dẹn hoogste tot den laagste toe, een vast douceur, dat naar rato van ieders gage

${ }_{1}$ Blijkens de Scheepsboeken van de bodems Spieringshoek 1730, Paddenburg 1735, Roosenbeek 1741.

2 Vgl. de artikelbrieven van $1634,1658,1672$ en 1742 resp. art. $14,14,14,15$.

3 Barchewitz, a. w. S. 669.

4 Het Kanaal van St. George tussehen Groot-Brittannië en Ierland.

s Aanmerkingen over den jegenwoordigen toestand enz. 
werd berekend en voor de matrozen en soldaten onderscheidenlijk honderdvijftig en honderd gulden bedroeg ${ }^{1}$. Met het invoeren van die premie, welke de Compagnie naar een in 1776 opgemakkte raming jaarlijks op een uitgave kwam te staan van bij de vier en een halve ton gouds ${ }^{2}$, zochten de Zeventien voor goed den particulieren handel te fnuiken, het groote euvel waaraan 's Compagnie's negotie van den tijd harer oprichting af heeft te lijden gehad. In weerwil toch van het verbod, daar reeds in den artikelbrief voor de vloot van Cornelis Houtman tegen uitgevaardigd ${ }^{3}$, werd er al in Augustus 1603 ter vergadering van de Zeventien luide over geklaagd dat de hoogstgeplaatsten zoo goed als de geringsten, kortom een iegelijk, handel dreven op eigen hand, zoo voor zichzelf als voor anderen, die hun tegen een aandeel in de winst contanten en koopmanschappen medegaven, niet zelden tot aanzienlijke bedragen toe ${ }^{4}$. En aldus ging het de geheele $17^{\mathrm{e}}$ en $18^{\mathrm{e}}$ eeuw door. Wie maar konden voorzagen zich op de uitreis van geld en goederen om er in Indië handel mede te drijven, pakten als zij van daar repatrieerden hun kisten en kanasserkorven vol met de fijnste porceleinen en lakwerken, met edelgesteenten en rariteiten van allerlei aard, teneinde ze in het Vaderland met grove winst te vertieren, of zij namen, zoo het hun zelf aan middelen tot het doen van aankoopen ontbrak, van dezen en genen koopman tegen een aandeel, bijvoorbeeld de helft, in de winst goederen ter bestelling mede. Waren er, wier bedrijfskapitaal voor hun handelsbedrijf in Indië niet groot genoeg was, zij verkochten of verpandden hun vordering op te goed hebbende gage, of bedienden zich onbeschaamd weg van de kapitalen en goederen, hun door de Compagnie ter administratie toebetrouwd. Anderen schoten aan Chineezen of inlandsche kooplieden geld op rente voor tot het opkoopen van peper en wat dies meer zij, wat de waren op prijs deed blijven en de Compagnie noodzaakte ze zooveel te duurder in te koopen. Weer anderen dreven handel hetzij op den naam van inlanders, hetzij met inlanders geassocieerd. In één woord, men kon geen praktijken en kunstgrepen

1 Reglement van 15 Nov. 1742.

2 Blijkens de „Consideratiën wegens het afschaffen der premiën van repatrieerende personen", door de Kamer Amsterdam ter vergadering van Oct. 1776 overgegeven en achter de notulen der Zeventien als bijlage opgenomen.

3 Artikelbrief van 16 Januari 1695 art. 22.

4 Res. Zeventien 5 Aug. 1603 point van beschrijving 22. Dl. 69 
bedenken of zij werden in den particulieren handel toegepast. Niet dat het aan verordeningen ontbrak, waarmede de Bewindhebbers het misbruik poogden uit te roeien. Integendeel, hun naam was legio. Daar waren verboden om voor eigen rekening of op bestelling van anderen gelden, goederen en geschenken van hier mede te nemen of herwaarts over te brengen; om goederen te lossen of vaartuigen aan boord te laten komen vóór men de bestemde haven had bereikt; om, tenzij bij alleruitersten nood, Fransche, Engelsche of andere vreemde havens aan te doen; om particuliere brieven te bezorgen of ter bezorging mede te geven; om gelden uit Indië mede te brengen of over te maken anders dan bij wissels, door de Compagnie's comptoiren in Indië op die in Patria getrokken; om in Indië Lijn maandgelden te verkoopen of te verpanden; om daar te lande kapitaal op rente uit te leenen enz. enz. Al die verbodsbepalingen wisselden af met bedreiging van straffen, welke hun naleving moesten verzekeren: confiscatie van het medegenomen goed, verbeurte van maandgelden, douceurs en premiën, verlies van ambt en rang en van de bevoegdheid om de Compagnie nog langer te dienen, openbare geeseling, bannissement, doodstraf enz., doch geen eed op den artikelbrief, gelijk die vóór het uitzeilen van een ieder werd afgevergd, geen plakkaten noch straffen waren bij machte het kwaad te keeren. Toen de Gouverneur-Generaal Hendrik Brouwer in 1632 naar Indië zeilde, liet hij op zekeren dag op zijn schip de kisten van de bemanning visiteeren en na afloop andermaal afkondigen, dat de manschappen op verbeurte, gelijk de artikelbrief voorschreef, van de helft hunner te verdienen gage "zouden overleveren alle brieven, zoo zij nog onder haar mochten hebben, alsmede van eenige pakskens of iets anders, dat hun mochte wezen medegeven, met verklaringe dat, zoo namaals konde bewezen worden dat iemand eenige brieven ofte iets anders zoude achtergehouden hebben, dat hij zoude vervallen in de vermelde pene, al ware het lange na dezen, en daarenboven arbitralijk gestraft te worden.» De uitslag was dat er in alles niet minder dan omtrent vijftienhonderd brieven en den volgenden dag op een ander schip van de vloot alweder een negenhonderdvijftigtal ingeleverd werden. Toch had men nog niet scherp genoeg toegezien, want een week later kwam het aan het licht dat een botteliersmaat onder zich gehouden had niet alleen eenige brieven 
maar ook een "groote dooze met koopmanschap», door zekeren Amsterdamschen koopman aan een vrijburger te Batavia geadresseerd met een recommandatie er bij om den botteliersmaat voor zijn besteldienst met een flinke vereering te beloonen. Niettegenstaande de scheepsofficieren "wegens zijn voorgaande getrouwe comportementen» een goed woord voor hem deden, vond de Gouverneur-Generaal het noodig een voorbeeld aan hem te stellen, en dies werd hij overeenkomstig den artikelbrief veroordeeld om, met verbeurte van de tot dusver door hem verdiende maandgelden, "gedeporteerd te wezen en te blijven» van zijn post en als matroos of soldaat met een soldij van acht gulden in de maand zijn verbonden tijd te gaan uitdienen op een van de Banda-eilanden ${ }^{1}$, berucht om hun ongezond klimaat zoowel als omdat er zelfs voor contant geld geen andere leeftocht te bekomen was dan droge rijst, en de gewone strafkolonie voor de booswichten en galgebrokken van gansch Indië ${ }^{2}$.

De publieke opinie zag trouwens in deze schennis van eed en plicht zoo weinig kwaads, naar het schijnt, dat ettelijke oudgedienden van de Compagnie, als zij later hun lotgevallen te boek stellen, zonder blikken of blozen om niet te zeggen met zeker welbehagen aan hun lezers mededeelen, op wat wijze zij er alle visitatiën ten spijt in geslaagd zijn met hun particuliere handelsondernemingen een aardige winst te bemachtigen. Hoort bij voorbeeld hoe Hendrik Hagenaar, die op het allerlaatst van 1637 uit Japan ter reede van Batavia aankwam, zijn wedervaren verhaalt: "den 31 dito (December 1637) voer nevens den fiscaal aan boord om zijn plunje te lossen, bestaande in een kist, daar zijden stoffen in lagen, dertien à veertien baliën porcelein, haar vieren in compagnie toebehoorende, anderhalve pikol benzoin, twee kleirıe kanassers dito hem vereerd en voor buit bekomen uit een genomen fregat nevens een kamferkist». Wel werd dit alles door den fiscaal voor verbeurd verklaard, "maar na den maaltijd, die met den heer Generaal ${ }^{3}$ hield, is hem toegestaan de kist met zijden stoffen; belangende het porcelein is geaccordeerd dat de fiscaal daar zes baliën af

1 Journaal uitgaand schip Zutphen, gehonden door Hendrik Brouwer (17, 18 on 26 Aug. 1632).

2 Barchewitz, a. w. S. 115, 181.

s Dat is: den Gouverneur-Generaal. 
hebben zoude, doch de benzoin bleef in den loop». ' Toen ik in December 1721 te Batavia voor de terugreis naar Nederland scheep ging, vertelt een ander, bevonden zich twee kaffers ${ }^{2}$ van den fiscaal aan boord, die voor hem onderzoeken moesten of er ook waren, die meer dan één kist aan boord brachten. "Ik had een weinig last van deze vogels (zegt hij) daar zij mijn kooigoed niet wilden doorlaten, toen ik hun echter een ducaton ${ }^{3}$ in de hand stopte lieten zij het passeeren: liever dan het kooigoed achter te laten had ik hun wel drie ducatons geschonken, want ik had twee kanassers thee, die meer dan een centenaar wogen, en honderdvijftig rottings daarin gebonden ${ }^{4}$. Wanneer een schip in het Vaderland terugkeert, vermeldt een derde, worden de kisten van het volk op het Oost-Indische Huis gebracht en aldaar bewaard totdat er een dag wordt bepaald, waarop een ieder de zijne kan gaan afhalen. "Elk heeft vrijheid om aan Indische waren een waarde mede te brengen van vier maanden gage, daarom moet ieder zijn kist in het bijzijn van twee Bewindhebbers openen. Is zij te groot voor zijn qualiteit ${ }^{5}$ of bevat zij te veel aan waarde, zoo wordt zij niet doorgelaten, doch de sluwheid van den een of den ander kan hier veel aan toe- of afdoen. Want indien er velen zijn die weinig of in het geheel niets hebben, aan den anderen kant zijn er ook verscheidenen, die twee of drie kisten hebben en ze door de anderen laten afhalen». Te Middelburg, waar deze schrijver zich ontscheepte, "werden de kisten op het Oost-Indische Huis afgegeven, wat op de volgende wijze toeging. Zoodra de bepaalde dag daar was, ging ik met anderen naar het Huis, waar de kisten op en door elkander stonden, en terwijl twee heeren Bewindhebbers tegenwoordig waren ging ieder, wiens kist voor de hand stond, binnen, en nadat hij ze geopend had tilden de Bewindhebbers er eenige stukken goed uit op om te zien

1 Journaal Hendrik Hagenaar (30 en 31 Dec. 1637), kennelijk naar een door hem zelf opgesteld journaal uitgegeven in Begin en Voortgangh II.

2 De naam voor de zwarte dienaars der officieren van de Justitie te Balavia, zie Van der Chijs, Nederl. Indisch plakaatboek II blz. 512.

3 Een zilveren ducaton was waard $\mathrm{f} 3.15$.

4 Barchewitz, a. w. S. 622.

s $\mathrm{Bij}$ verschillende reglementen was met de grootste nauwkeurigheid vastgesteld hoeveel kisten elk schepeling aan boord mocht brengen en hoe groot zij mochten wezen. Getal en grootte waren geregeld in verhouding tot zijn rang en qualiteit. 
of er ook contrabande onder lag. Wanneer zij nu voor de qualiteit van den eigenaar niet al te groot was, werd de kist weder gesloten en er een teeken van krijt op gezet, dat zij passeeren mocht. Ik had er twee kisten in, een van mijzelf en een op halve winst, ik ging binnen en opende mijn eigen kist eerst, bij welke gelegenheid mij gevraagd werd waar ik voor gediend had en hoelang ik in Indië was geweest. Daar zij een beetje te groot was, antwoordde ik: tien jaar, wel wetende dat de beide heeren er toch niet van op de hoogte konden wezen of ik daar lang of kort had vertoefd. $Z_{i j}$ wezen er mij wel op, dat ik voor mijn qualiteit te veel had, maar ik klaagde dat ik ginds op ongezonde plaatsen had gelegen en daar mijn gezondheid bij verloren had, dat dit dus het eenige was waarvan ik leven moest, ${ }^{1}$ waarop zij de kist lieten volgen. Den volgenden dag ging ik er heen met een ander, een matroos die nimmer in Indië was geweest, dezen gaf ik twee rijksdaalders waarvoor hij de kist, die ik op halve winst had medegebracht, afhaalde en liet visiteeren kwansuis alsof zij van hem zelf ware. En al zoude men die ook niet doorgelaten hebben, zoo had ik er toch niets bij verloren dan de halve winst, welke na verkoop van het daarin gepakte goed tachtig rijksdaalders bedroeg. Het adres van die kist was aan een koopman te Amsterdam. Van de waren, welke ik zelf medebracht, bestond het meeste uit porcelein. Wat mij nu in de Oost een goede drie dubbeltjes had gekost daar kon ik in Holland een rijksdaalder van maken». ${ }^{2}$

Men ziet, het vuur werd de in het Vaderland teruggekeerde oudgasten bij de visitatie niet al te na aan de schenen gelegd. «De ordres tot het aanhouden van alle particuliere overgebrachte koopmanschappen lagen wel strikt en precies, maar (het is de advocaat der Compagnie Pieter van Dam zelve die het getuigt) maar dezelve zijn nooit in dier voegen naar de letter opgevolgd en geëxecuteerd, ter contrarie hebben de Kameren of die daartoe zijn gecommitteerd geweest veel door de vingeren gezien en laten volgen hetgene notoirlijk naar den artikelbrief hadde behooren aangehouden geweest te zijn, behalve dat de eene Kamer nu en dan vrij liberaler daarin heeft gegaan als de

1 "Dasz also dieses eintzig und allein mein Lebensbehülff wäre”.

2 Langhansz a. w. S. 37, 38, 655-657. De „drei guten groschen", waarvan de schrijver hier spreekt, stelt hij op een andere plaats van zijn boek (S. 613) gelijk met een Hollandschen schelling. 
andere, ook zooals de humeuren van de commissarissen dan dus dan zoo hebben gelegen, den eenen tijd daarin wat scherper geweest of nauwer gezien hebben als den anderen». ' En echter zou, naar zijn gevoelen, alleen een gestrenge visitatie het euvel hebben kunnen wegnemen. "Indien men daartoe konde komen (zegt hij) en zich in staat vond om alles aan te houden 'tgene tegen den artikelbrief wordt overgebracht en specialijk de bestelgoederen, en dat effective kon practiseeren, men zoude het werk te boven zijn, en dat schijnt ook het eenigste middel te wezen dat de Compagnie zoude kunnen zoo niet behooren te gebruiken, maar voorziende dat de Kameren dat niet alle zouden opvolgen en malkanderen daarin getrouw zijn; dat ten opzichte van deze en gene kleinigheden als thee en dergelijke, aan heeren van conditie en qualiteit geadresseerd, dispensatiën zouden moeten vallen en dat op de eene dispensatie de andere zoude komen te volgen, of anders dat de Compagnie een groote hatelijkheid op haar hals zoude halen en vooral wanneer men dat alles ten profijte van de Compagnie kwam te verkoopen, is dat zoo op zijn beloop gelaten, een kwaad hetwelk zich al voor het oprichten van de Compagnie heeft geopenbaard en tot nog toe niet kunnen uitgeroeid worden». ${ }^{2}$ Nog slapper misschien werd aan de handhaving der verbodsbepalingen de hand gehouden in Indië. Daar, zoo ergens, gold het woord door Van Dam op een andere plaats van de Companie in het algemeen neergeschreven: "de reglementen zijn wel loffelijk maar het hapert aan de executie». Volgens Nicolaas de Graaff, die de toestanden aan gene zijde van den Evenaar gedurende de $17^{\mathrm{e}}$ eeuw uit eigen aanschouwing kende, propte men de voor Japan bestemde schepen te Batavia somwijlen zoo boordevol met particuliere koopmanschappen, "dat men er kwalijk een kat bij den staart kon uithalen", terwijl de schuiten, welke de Compagnieswaren aanvoerden, meermalen, slechts half of wel in het geheel niet gelost, door de schippers en stuurlieden weder naar den wal werden teruggestuurd met de boodschap dat het schip geheel was volgestuwd. De schaamteloosheid, waarmede met name in Bengalen de particuliere handel oogluikend werd toegelaten, tartte alle gevoel van eerlijkheid en goede trouw. Zoodra de schepen bij hun aankomst aldaar door den fiscaal

1 Van Dam, a. w. Boek III cap. 21 fol. 380.

2 Als voren fol. 383 . 
waren gevisiteerd, kondigde men plechtiglijk een bevelschrift af, dat niemand zich vermeten zou eenige particuliere kisten of pakken naar of van boord te brengen zonder bijzonder verlof van den directeur of fiscaal - wat niet belette dat schippers, stuurlieden, in het kort jan en alleman, des anderen daags hun goederen voor de oogen van ieder aan land brachten en in gehuurde pakhuizen opsloegen om er van dag tot dag hun klanten mede te kunnen gerieven, gezwegen van de groote hoeveelheden amfioen, katoenen kleedjes en dergelijke, die onderwijl men op de reede lag voor particuliere rekening als retourvracht werden ingeladen niet enkel ter sluiks maar nu en dan zelfs op klaarlichten dag. Niemand, zegt de Graaff, behoefde bevreesd te zijn hoe hij zijn goed aan land of wel aan boord zou kunnen krijgen, want al hielden de "pioens» ook dag en nacht met hun schuitjes rond de schepen de wacht «eenige zilveren ropijen doen haar geheel verblinden en de fiscaal - is van alles onwetend!» 1 Dat zijn schildering in geenen deele te zwart is gekleurd, dat hij integendeel maar een tipje oplicht van den sluier, toonen de berichten van een auteur, die Indië heeft bereisd in het begin van de $18^{\mathrm{e}}$ eeuw. "Intusschen naderde de tijd (schrijft hij van zijn verblijf in Bengalen) dat de schepen, met welke men de Bengaalsche goederen naar Batavia en Ceilon zou afvaardigen» stonden te vertrekken. «Dit deed de bouwtijd des Bengaalschen fiscaals daar zijn, die reeds alleen van onzen bodem over de vierduizend ropijen getrokken had, alzoo de scheepsoverheden hun sjanken ${ }^{2}$, door gunst ${ }^{3}$ op Tutekorijn bekomen, anders niet konden of mochten te lande brengen. Hij zelf, verplicht den algemeenen handel te beletten, was alleen de opkooper der aangebrachte waren schoon hij anderen daartoe gebruikte, nadat hij de markt op de komste der schepen had doen slappen, en trok daarenboven nog groote gelden om dezelve te mogen te lande brengen en te vermangelen *. Niet leniger handelde hij op het vertrek der schepen. Die amfioen begeerde moest bij hem verzoekenderwijze te markt

1 De Graaff, a. w. blz. 17 vlg.

2 Volgens Yule en Burnell, Hobson Jobson, a glossary of Anglo-Indian words (i. v. chank), een soort van kinkhorens, door de Hindoes gebruikt voor het plengen van drankoffers, het maken van hoorngeschal in tempels, en het vervaardigen van armbanden en andere sieradiën.

3 Te weten door particulieren handel.

- Vertieren, verruilen. 
komen, zich met den prijs dien hij te stellen kwam vergenoegen, en daarenboven tien rijksdaalders voor de vrijheid der afscheping van ieder kasje aan hem tellen" ${ }^{1}$. En ziehier wat diezelfde schrijver bij zijn aankomst te Batavia zag gebeuren: "ten volgenden dage kwam ons de waterfiscaal volgens een aloude gewoonte aan boord bezoeken om het belang der Maatschappije tegen den verboden handel harer dienaren te behartigen, een zaak die thans maar om de sleur gedaan wordt overmits het goud die krachten schijnt in te hebben van het gezicht met een wolk van duisternis te overtrekken, alzoo ik wel gezien heb dat men in zijn bijzijn monsterde en te dien stonde een menigte van peper openlijk inscheepte om die in Bengalen ten nadeele der Maatschappij te vermangelen, zonder dat zijn oogen hoe doordringende ook zulks zien konden. Nauwelijks was hij vertrokken of een menigte van Hollanders en Chineezen wonende op Batavia stapten uit hunne vaartuigen om waar het hun het gereedste viel hun voordeel te bejagen. Men opende kisten en kassen en het krioelde op het halfdek, in de bak en konstapelskamer van menschen, noch gaf matroosje, die wat had, zijn gebieders tusschen deks toe. Wijnen, bieren, brandewijnen, stoffen, lakens, hoeden, tabak en pijpen mitsgaders alle soorten van kramerije, versnaperingen en eetwaren vonden haar koopers, die aanstonds betaald aanstonds overgenomen werden. Dit duurde zoo eenige dagen, waarna de toevloeiing merkelijk minderde alzoo men thans ook doende was om de goederen der Maatschappije te lossen». ${ }^{2}$. Zóóver was het in zijn dagen in Indië gekomen, dat «alle schroomvalligheid» omtrent het drijven van particulieren handel daar te lande "zelfs van diegenen bespot werd, die gemachtigd waren om hetzelve te verhinderen" ${ }^{3}$. Wanneer bijvoorbeeld, om maar bij Batavia te blijven, de schepen de voor de reede liggende eilanden naderden, stelden de schipper en de voornaamste officieren naar rato van het bedrag, dat elk hunner voor zijn aankoopen had besteed, de vereering vast, die hij voor den fiscaal, den provoost-geweldiger en den boomwachter had gereed te houden. Zoodra nu de geweldiger zijn fooi in handen had gekregen, verscheen hij aan

1 Abraham Bogaert, Historische reizen door d'oostersche deelen van Asia, blz. 422 .

2 Bogaert, a. w. blz. 125.

s Bogaert a. w. blz. 165. 
boord, liet, zoogenaamd om zijn plicht niet te verwaarloozen, een luik openen, stak daar eventjes het hoofd door, verklaarde zich daarop met een brusk "doet de luiken toe» voldaan, en begaf zich vervolgens weer met zijn dienders aan land. Thans stond aan degenen, die particuliere koopmanschap hadden medegebracht, niets meer in den weg, zij scheepten die in kleinere vaartuigen over en kwamen er, na ook den boomwachter de handen te hebben gezalfd, onverlet mede in de stad. Had men hen bij den fiscaal verklikt dan was, mits de zaak maar niet al te ruchtbaar was geworden, een schuldbekentenis voor zooveel honderd of duizend rijksdaalders, kwansuis wegens van hem te leen ontvangen gelden, voldoende om alles in het effen te doen komen en alle verder onderzoek te smoren. Anders liep het natuurlijk af indien het gerucht van het gebeurde de gansche stad was doorgeloopen. In dit geval sloeg de fiscaal op bevel van Gouverneur-Generaal en Raden de goederen aan en moest het vergrijp met verlies van goederen, verbeurte van maandgelden en ontzetting uit het ambt worden geboet. Veelal echter duurde het niet lang of de gestraften werden wederom in hun eer en bediening hersteld en zoodoende in de gelegenheid gebracht om de geleden schade in te halen, bijvoorbeeld door een tocht naar Japan of Bengalen, waarop zij somtijds, zoo wij. De Graaff mogen gelooven, winsten verdienden van honderdzeventig, tweehonderdtachtig tot zeshonderd procento. ${ }^{1}$ Aanzienlijken en geringen, de minste matroos zoo goed als de hoogste officier, maakten zich aan het misdrijf schuldig ${ }^{2}$, en zij ondervonden hierbij, gelijk wij reeds hoorden, juist van den kant van diegenen, die er eeds- en plichtshalve tegen behoorden te waken, de meeste oogluiking, ja zelfs de meeste medewerking, want naar men verzekert waren bepaaldelijk de fiscalen in Indië de voornaamste opkoopers van de aangevoerde verboden goederen. ${ }^{3}$

Wat nadeel die "morshandel» der Compagnie berokkende, valt in het oog. Niet alleen kwam zij er de benoodigde scheepsruimte door te derven voor haar eigen koopwaren maar tegelijk was de hoeveelheid particuliere goederen, welke men in de kajuit en elders in het bovenschip optaste, zóó geweldig dat

I De Graaff a. w. blz. 21.

${ }^{2}$ De Graaff, a. w. blz. 22.

s Bogaert, a. w. blz. 165. 
er door den enormen opperlast te veel gevergd werd van het verband van de schepen, wat ze deed inbuigen en in weinig jaren tijds ten eenenmale onbekwaam maakte om bij zwaar weder zee te bouwen of naar behooren te rijzen, daargelaten nog dat zij van wege de onklare dekken bij ontmoeting van vijanden buiten staat waren den vereischten tegenweer te bieden. ${ }^{1}$

Teneinde het hieruit voortspruitend gevaar voor het verlies van de schepen voor te komen, vonden de Zeventien in 1693 goed om aan hun bedienden in Indië en de van daar overkomende vrije luiden toe te staan, dat zij tegen betaling van vracht op de retourreis eenige bepaalde goederen medebrachten, als thee, theegereedschap, porceleinen, Tonkinsche mandjes, atjar $^{2}$ en dergelijke, waar de Compagnie toenmaals van wege de geringe winst, die zij opleverden, geen handel in dreef. ${ }^{3}$ "Maar dat is almede niet geweest van dat effect (bericht Van Dam), dat men daarvan hadde gewacht, als zijnde dit jaar zeer weinig goederen van die natuur overgebracht, zulks dat de vracht daarvoor ontvangen geen naam konde voeren, de luiden, zooals men uit Indië schreef, scrupuleus gemaakt zijnde daarin iets te doen of te riskeeren, en in het tweede jaar alles weer op den ouden voet kwam te gaan, in voegen dat, na langwijlige deliberatiën en rijpe overweging van alles, eindelijk en ten laatste gemeend en verstaan is dat zulks behoorde geweerd te worden ${ }^{4}{ }^{4}$

Een soortgelijke, doch veel radicaler maatregel werd in 1742 genomen. Terwijl bij een vroeger reglement, van October 1713, aan de schippers, kooplieden, onderkooplieden, assistenten, sergeants, opperchirurgijns, ziekentroosters, opperstuurlieden, onderstuurlieden en derdewaken was vergund op de uitreis als vrijgoed een zekere hoeveelheid mede te nemen van wijn, bier en eenige andere met name genoemde waren ${ }^{5}$, werd die voor zooveel de wijnen en bieren aanging in November 1742 tot op de helft verminderd en voorgeschreven, dat alwie er meer van begeerde in te laden van elke halve pijp of aam een recognitie

\footnotetext{
1 Van Dam, a. w. Boek III cap. 21 fol. 383 vlg.

2 In het zuur gelegde lekkernijen.

3 Res. Zeventien 28 Febr. 1693.

4 Van Dam, t. a. p.

5 Res. Zeventien 30 Oct. 1713.
} 
aan de Compagnie zou hebben te betalen van vijf gulden hier te lande en vijf rijksdaalders bij zijn aankomst te Batavia.

Ten aanzien van de retourschepen werd de zaak aldus geregeld, dat men de tot hiertoe aan de opperofficieren "gepermitteerde bagage» afschafte, met uitzondering alleen van de kisten, kelders enz., welke hun bij het reglement van 1717 waren vergund ${ }^{1}$, en dat aan alle andere schepelingen verboden werd voortaan eenige kisten, kanassers en kooigoed ${ }^{2}$ mede te brengen behalve één kist tot het opbergen van hun plunjes voor elk baksvolk gezamenlijk, zoodanig dat bij hun aankomst in het Vaderland "inderdaad maar met het bloote lijf van boord gingen. Voor het verlies, hun door dit verbod toegebracht, kenden de Zeventien hun bij wijze van equivalent een douceur of premie toe in geld, welke voor de soldaten honderd, voor de matrozen honderdvijftig en, aldus naar verhouding van ieders rang opklimmende, voor de schippers tot twee- en drieduizend gulden beliep. ${ }^{3}$

Ofschoon deze premie haar volgens een begrooting van 1776 met een jaarlijkschen last bezwaarde van vierhonderddertig duizend gulden ${ }^{4}$, schijnt de Compagnie er toch haar oogmerk, de uitroeiing van den verboden handel, niet mede te hebben bereikt, want in 1749 , verklaart een tijdgenoot, "zijn er met eenige Bengaalsche retourschepen particulier aangebracht en achterhaald geworden zoodanige goederen, dewelke alleene ter Kamere Amsterdam bij publieke vendutie hebben komen te rendeeren ruim negenhonderdzestigduizend gulden, doch omtrent welken horribelen handel bij de overige Kameren is gebruikt conniventie» 5 . Zelfs weet hij den naam te noemen van een gewezen Indisch ambtenaar, die op zijn terugreis in 1750 "onder meer andere koopmanschappen van importantie» alleen

1 Res. Zeventien 5 Oct. 1717.

" Onder de benaming van „kooi- of slaapgoed" werden blijkens het plakkaat van Gouverneur-Generaal en Raden van 6 Oct. 1724 (Van der Chijs, Nederl. Indisch plakaatboek IV blz. 179) maar al te dikwijls "diverse zware pakken" aan boord van de retourschepen gebracht, „die ten meerendeele met koopmanschappen waren gevuld."

3 Res. Zeventien 15 Nov. 1742.

- Zie hiervóór blz. 394

5 Aanmerkingen over den jegenwoordigen staat van de generale O.-I. Compagnie in Indië (Papieren Radermacher), ook Stavorinus, Voyages to the East Indies, London 1798, I p. 398, is van oordeel dat de premie van 1742 weinig of niets uitwerkte. 
aan fijne KoromandeIsche "neusdoeken» voor eigen rekening een voorraad medebracht, die in openbare veiling honderdnegenendertigduizend gulden besomde ${ }^{1}$. Een ander, die in 1793 de Kaapstad bezocht, verhaalt dat de kapiteins en de mindere bevelhebbers van de Compagniesschepen daar ongestoord verboden handel dreven in koffie, thee, rijst en andere Indische producten, welke door de kolonisten gretig werden opgekocht. Doordien de profijten hoe meer men in de schepen laadde des te grooter waren, zoo zegt hij, lagen zij nooit dieper dan op de reis van Batavia naar de Kaap. Dientengevolge werden de reizen trager en kostbaarder meteen, "het volk, door het klimaat van Batavia reeds afgemat en nu langer op zee, stierf, en wie zal durven bepalen (roept hij uit) hoevele schepen door het onverstandig laden of door de sterfte van het volk gebleven en verloren zijn! De strengste wetten hadden hun kracht verloren, men stond het zelfs oogluikende toe daar de geheele volksplanting in de voordeelen deelde». ${ }^{2}$

Tegenover de verdiende gages of maandgelden, de premiën voor de vaart achterom en het lossen der schepen, het douceur van 1742 en meer andere verdiensten en emolumenten van de manschappen, stonden op hun rekening als debetposten te boek het bedrag van de op de hand gegeven gage, van hun transportceel of schuldbrief, alsmede van hetgeen zij bij hun maandbrief hadden "vermaakt»; de prijs van de hun van Compagnie's wege verstrekte kisten, kelders, pothuizen ${ }^{3}$, bultzakken, hangmatten en kleedingstukken en van de goederen, welke zij hadden aangekocht uit hetgeen door overledenen, gedrosten, van boord gezondenen enz. achtergelaten en in het openbaar onder de bemanning verkocht was; de hospitaalsongelden of "hospitaalguasto's» wanneer zij aan de Kaap of elders, terwijl het schip voor den wal lag, in het hospitaal hadden vertoefd; de zoogenaamde "goede maanden" of "genot", dat is de contanten, meestal ten bedrage van een of twee maanden gage, hun onderweg voorgeschoten; de boeten die zij beloopen hadden en het sluitgeld, dat zij wegens hun opsluiting in de boeien aan den proovoost waren verschuldigd; de prijs van de doodkist

\footnotetext{
1 Aunmerkingen als voren.

2 Cornelius de Jong, Reize naar de Kaap de Goede Hoop enz. in de jaren 1792-1797, Haarlem 1802, I blz. 150 vlg.

3 Dat is: kisten voor het bergen van de timmermansgereedschappen dienende.
} 
voor de overledenen met de kosten van de begrafenis benevens de zwaarte van de kogels, van het schroot en dergelijke, dat bij de lijken werd gevoegd die men overboord zette. ${ }^{1}$ De meeste van de hier genoemde posten zijn of op zich zelf te duidelijk om opheldering te behoeven of door het hiervóór medegedeelde reeds voldoende toegelicht. Alleen nog een enkel woord over de maandbrieven, ook acten, biljetten of maandceduls geheeten. Dit waren acten, waarbij iemand de Bewindhebbers van de Kamer voor welke hij uitvoer verzocht om, zoolang hij op reis was, aan dezen of genen jaarlijks eenige maanden van zijn gage uit te keeren, "te weten zoo wanneer de scheepsboeken, zijn rekeningen $^{2}$ of andere genoegzame bescheiden overgekomen zouden zijn en daarbij bleek dat hij op zijn verdiende gage telkens te goed had». ${ }^{3}$ Had het voorheen aan de schepelingen vrij gestaan geld per maandbrief te "vermaken" aan wie het hun beliefde, sedert 1682 kon dit alleen geschieden ten behoeve van ouders, vrouw en kinderen en tegen geen hooger bedrag dan drie maanden gage in één jaar ${ }^{4}$. Verkreeg iemand gedurende zijn diensttermijn een hoogere wedde, dan werd aan den houder van den maandbrief ook een naar evenredigheid verhoogde uitkeering gedaan. ${ }^{5} \mathrm{Bij}$ overlijden van de vrouw van den "verleener» bleven zijn kinderen de haar besproken som genieten totdat zij in staat waren hun eigen brood te verdienen. ${ }^{6}$ Wanneer iemand vóór zijn vertrek naar Indië verzuimd had voor het onderhoud zijner vrouw of kinderen een maandbrief te passeeren, zoo kon haar die op vertoon van haar trouwbewijs en een getuigschrift van goed gedrag ook verleend worden door de Bewindhebbers. ${ }^{7}$

Niemand was gerechtigd de aan zijn vrouw of kinderen vermaakte maandbrieven in te trekken of te herroepen tenzij met

I Blijkens de Scheepsboeken.

2 Met rekeningen bedoelde men de geauthentiseerde uittreksels uit de boeken, die op de schepen en comptoiren werden gehouden, waarop iemands debet en credit stond uitgedrukt, zie Langhansz., a. w. S. 87.

s Blijkens het formulier, vastgesteld bij resolutie Zeventien van 12 April 1658.

4 Res. Zeventien 21 Febr. 1682. De vermaking geschiedde ook wel aan een diaconie, die met het onderhoud van de kinderen des verleeners was belast, zie de Scheepsboeken ran Westkappel en Looverendaal, 1738.

s Res. Zeventien 12 April 1658.

6 Als voren.

7 Res. Zeventien 19 Aug. 1671. 
opgave van de redenen, die hem daartoe bewogen, welkẹ redenen aan de betrokkenen moesten worden medegedeeld, opdat zij gelegenheid zouden hebben er zich tegen te verdedigen en door de Bewindhebbers naar bevinding van zaken daarin zou kunnen beslist worden. ${ }^{1}$ Voorts hadden de Zeventien bepaald dat wie minder dan zeven gulden ter maand won niet bevoegd was om een maandbrief te verleenen ${ }^{2}$, alsmede dat deze vrij waren van arrest ${ }^{3}$ en preferent voor de transporten of schuldbrieven ${ }^{4}$, Die, welke aan ouders, vrienden of anderen waren vermaakt, vervielen wanneer de verleeners in Indië huwden wijl zij alsdan het geld zelve voor hun huishouding van noode hadden, uitgenomen echter de zoodanige, die zij aan hun kinderen hadden besproken, deze namelijk bleven van kracht totdat de kinderen oud genoeg waren om zelf in hun onderhoud te voorzien ${ }^{5}$. Eveneens werden $\mathrm{zij}^{\mathrm{ij}}$ als vervallen beschouwd zoo degenen, tot wier behoef zij waren gepasseerd, kwamen te sterven ${ }^{6}$ of de verleeners uit Compagnie's dienst deserteerden ${ }^{7}$. De betaling geschiedde door de Kamer, voor welke de verleener was uitgevaren, soms ook op haar speciale machtiging door een van de andere Kameren, of wel door de Hooge Regeering en andere autoriteiten in Indië. ${ }^{8}$ Indien iemand behalve zijn maandbrief aan ouders, vrouw en kinderen bovendien nog een transportceel of schuldbrief aan derden had gemaakt, mocht de laatste niet worden voldaan vooraleer op de gage zooveel was te goed gelaten, dat daar allereerst de maandbrief uit kon worden betaald, ook al was door den verleener bij notariëele acte beschikt dat de transportceel vóór den maandbrief moest gaan en deze laatste met dat oogmerk zelfs aan den houder van de transportceel ter hand gesteld. ${ }^{9}$ Ook werd de overdracht van maandbrieven aan de houders der transportceelen eerst dan voor geldig aangemerkt wanneer zij

1 Res. Zeventien 28 Maart 1685.

2 Res. Zeventien 5 April 1697.

s Res. Zeventien 19 Aug. 1671, 12 Mei 1672, 20 Juli 1707.

4 Res. Zeventien 20 Aug. 1670 en 5 April 1697.

s Res. Zeventien 19 Nov. 1667.

6 Res. Zevention 11 Mei 1667.

7 Res. Zeventien 11 Maart 1718.

s Blijkens de Scheepsboeken van Het Noorderkwartier 1723, Hillegonda 1724 enz.

9 Res. Kamer Amsterdam 26 Febr. 1671. 
had plaats gehad door degenen, tot wier behoef zij luidden en dat wel nà het vertrek van den verleener en bij notariëele acte van overdracht. ${ }^{1}$ Voor maandbrieven, op die wijze overgedragen aan derden, en voor dezulke, die aan dezen of genen bij procuratie tot het ontvangen van de besproken uitkeering waren in handen gesteld, moest telken jare een nieuwe acte van overdracht of volmacht worden opgemaakt, in allen gevalle blijk worden vertoond dat de transportant of constituant nog in leven was ${ }^{2}$. Bij vermissing van de uit Indië herwaarts over te zenden soldijboeken werd aan ouders, vrouwen en kinderen, welke maandbrieven bezaten, de vermaakte som uitbetaald, voor zooverre de verleeners op de voorgaande boeken nog iets te goed hadden; was dit niet het geval zoo waren de Kameren bevoegd om hun "naar gelegenheid van zaken uit commiseratie ietwes bij anticipatie te verstrekken" ${ }^{3}$. Doch ten aanzien van alle andere houders van maandbrieven en transportceelen gold het voorschrift, dat aan hen "niet anders noch verder zou worden betaald dan voor zooveel op de voorgaande boeken te goed stond.» 4

Niemand mocht, om het even of zijn diensttermijn afgeloopen was of niet, uit Indië terugkeeren alvorens hij daar van GouverneurGeneraal en Raden vergunning toe had bekomen, op verbeurte van zijn verdiende maandgelden ${ }^{5}$ en daarenboven als weglooper te worden gestraft. ${ }^{6}$ Wie zulke wegloopers en die zich heimelijk op de retourschepen verstaken ontdekte en verzuimde hen op de eerste plaats onder het gebied der Compagnie, daar men arriveerde, of bij terugkomst in het Vaderland aan de Bewindhebbers aan te geven, werd beboet met verlies van zijn maandgelden en tevens, naar bevinding van zaken, gestraft met "cassatie, deportement en inhabiliteit " ?.

De duur van den diensttijd, het zoogenaamde "verband", was, ongerekend den tijd doorgebracht op de uit- en thuisreis, door den artikelbrief van 1634 vastgesteld op drie jaar voor de schippers, stuurlieden en in het algemeen alle zeeva-

\footnotetext{
1 Als voren.

2 Als voren.

s Res. Zeventien 20 Oct. 1673.

4 Als voren.

5 Artikelbrieven 1634, 1658, 1672 en 1742 art. resp. 28, 28, 28 en 29,

6 Artikelbrief van 1742 art. 29.

7 Als voren.
} 
renden, voor de andere Compagniesdienaren op vijf jaar ${ }^{1}$. In de latere artikelbrieven werd echter bepaald dat degenen, die boven de zes tot tien gulden ter maand wonnen, zelfs al behoorden zij tot de zeevarende manschappen, vijf jaar moesten dienen ${ }^{2}$. Scheepsjongens hadden een verband van tien jaar ${ }^{3}$.

Eindelijk werd aan geen Compagniesdienaar, onverschillig van wat staat of rang, de terugkeer naar Nederland toegestaan zoo hij niet op zi.jn minst twaalf volle maanden gage aan de Compagnie te goed had, of wel het bedrag van dien door het Comptoir-Generaal te Batavia per wisselbrief naar Nederland liet overmaken. Blijkens de resolutie, bij welke deze maatregel in April 1660 door Gouverneur-Generaal en Raden werd ingevoerd, geschiedde dit omdat men vreesde dat anders "velen, voornamelijk soldaten en matrozen, wanneer zij haar verbonden tijd uitgediend hebbende zouden willen naar het Vaderland vertrekken, weinig te goed zouden hebben, hetwelk berooide hoofden en gevolgelijk onheilen op 's Compagnie's kostelijke retourschepen zoude kunnen veroorzaken" 4.

Helaas, of hun tegoed veel of weinig bedroeg, van het oogenblik af aan dat de matrozen en soldaten weer den vaderlandschen grond onder de voeten hadden en de gages hun door de Compagnie waren uitbetaald, kenden zij geen rust of duur meer voordat het zuurverdiende geld tot den laatsten duit toe was opgeteerd. Wat door het heerleger van kroeghouders, prostituées en dergelijke, die als roofvogels op hen aanvielen, aan de arme kerels werd overgelaten, gebruikten zij bij voorkeur om zich als prinsen langs 's heeren straten en wegen te laten rijden en bij zulke gelegenheden al de zaligheden te smaken, daar zij reeds maanden en jaren lang te voren van hadden gedroomd. "Kom ik», zoo plachten zij nog tijdens hun verblijf in Indië te

I Artikelbrief van 1634 art. 27. Bij resolutie Zeventien van 18 Oct. 1628 was het verband voor het bootsvolk en de officieren van hetzelve op vier jaar gesteld.

2 Artikelbrieven van 1658, 1672 en 1742 art. resp. 27, 27 en 28. Volgens De Graaft, Oost-Indische Spiegel, blz. 31 moesten zij, dic beneden de elf gulden verdienden, vijf; die elf gulden en meer wonnen drie jaar dienen, met uitzondering van de militairen, kooplieden, boekhouders en assistenten, die eerst na een vijfjarigen diensttijd hun ontslag of "verlossing" mochten vragen.

s Res. Zeventien 6 Aug. 1627; Artikelbrieven 1658, 1672 en 1742 art. resp. 27, 27 en 28; De Graaff a. w. blz. 31.

- Res. Gouverneur-Generaal en Raden 13 April 1660. 
spreken, "kom ik maar in Holland, ik wil er rijden dat er de steenen barsten». Hoe die lust door sommigen werd geboet, moge ons een schrijver verhalen, die het omstreeks 1700 persoonlijk had bijgewoond. Toen ik mij te Amsterdam bevond, zegt hij, op den tijd dat ik uit Indië huiswaarts keerde, waren daar eenige matrozen, die ieder voor hun persoon alleen drie rijtuigen afhuurden, tegen vier gulden het rijtuig, ongerekend de vertering welke onderweg werd gemaakt. In het voorste, dat van achter een prinsevlag op had en waarmede de koetsier zóó hard moest rijden dat de vlag altijd heelemaal uitwaaide, lag de hoed van den matroos, in het tweede zijn tabaksdoos en pijp, in het derde zat hij zelf. Hadden zij ten laatste in hun brooddronkenheid den buidel tot op den bodem toe geleegd, dan bleef voor deze "heeren van zes weken», gelijk de volkshumor ze noemde, niets anders over dan dat zij zich opnieuw bij de Compagnie lieten aanwerven, met het rijmpje op de lippen: "Sapitau ${ }^{1}$ weet geen beter raad, Als dat hij weer naar den zielverkooper gaat, En voor al zijn druk, Acht het hem voor geluk, Als hij maar weer naar Indië gaat» ${ }^{2}$.

1 Het Maleische woord siapa taoe (= wie weet het, weet ik het?), in het Hollandsch verbasterd tot sapitau of sjappetouw, was een uitdrukking, die matrozen en ander ruw volk dikwijls in den mond hadden, het beteekent dan zooveel als „ruwe klant, zeebonk, lichtmis enz.", zie Van Wijk, Etymo. logisch woordenboek der Nederlandsche taal, i. v. sjappetouwer.

2 Langhansz, a. w. S. 33-35. 